\title{
Fiskalna politika i ekonomski rast u novim članicama EU: analiza panel podataka
}

Dalić, Martina

Source / Izvornik: Odabrani prijevodi, 2013, 4, 1 - 24

Journal article, Published version

Rad u časopisu, Objavljena verzija rada (izdavačev PDF)

https://doi.org/10.3326/op.20

Permanent link / Trajna poveznica: https://urn.nsk.hr/urn:nbn:hr:242:041979

Rights / Prava: Attribution-NonCommercial-NoDerivatives 4.0 International/ImenovanjeNekomercijalno-Bez prerada 4.0 međunarodna

Download date / Datum preuzimanja: 2023-04-26

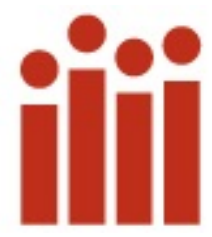

Institute of Public Finance Repository

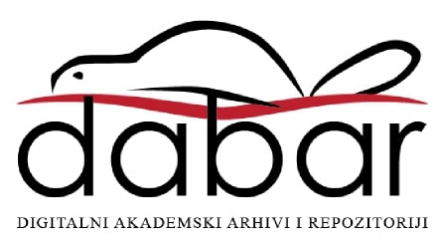


Institut za

javne financije

Smičiklasova 2I | Zagreb

www.ijf.hr | ured@ijf.hr

T: oI/4886-444 | F: oI/48I9-365

\section{OdABRANI}

\section{PRIJEVODI}

ISSN $1847-7445$

BR. 20/I3

\section{FISKALNA POLITIKA I EKONOMSKI RAST U NOVIM ČLANICAMA EU: ANALIZA PANEL PODATAKA}

\author{
ČLANAK $^{* *}$ \\ JEL: E62, $\mathrm{H}_{50}$ \\ DOI: $10.3326 /$ op.20
}

\section{SAŽETAK}

Fiskalna politika može pozitivno utjecati na ekonomski rast promjenama u strukturi ukupnih rashoda tj. snižavanjem neproduktivnih ili tekućih rashoda koje se koristi za financiranje rasta investicija i/ili snižavanje poreza. Dodatno, ovakve promjene omogućavaju smanjivanje ukupne veličine državnog sektora što pozitivno djeluje na gospodarski rast. Pozitivne učinke na rast ima i manja hirovitost u promjenama državnih investicijskih izdataka. Međutim, smanjivanje deficita ima najsnažnije pozitivne učinke na gospodarski rast koji su posebno naglašeni ukoliko se postižu smanjivanjem neproduktivnih rashoda. Ovo znači da oprezna fiskalna politika može biti najbolji način poticanja gospodarskog rasta.

Ključne riječi: gospodarski rast, produktivni rashodi, diskrecijsko oporezivanje, hirovitost, fiskalni saldo

citirati: Dalić, M., 20I3. "Fiscal policy and growth in new member states of the EU: a panel data analysis". Financial Theory and Practice, 37 (4), 335-36o.

http://fintp.ijf.hr/upload/files/ftp/ 20I3/4/dalic.pdf

Svi Odabrani prijevodi dostupni su na: http://www.ijf.hr/hr/publikacije/ca sopisi/I2/odabrani-prijevodi/III/
Autorica zahvaljuje trima anonimnim recenzentima na korisnim komentarima i prijedlozima. Primljeno: I3. veljače 2013. Prihvaćeno: 19. kolovoza 2013.

Zagrebačka škola ekonomije i managementa, Jordanovac IIo, Ioooo Zagreb, Hrvatska e-mail:mdalic@zsem.hr 


\section{UvOD}

Svrha ovog članka je istražiti utjecaj fiskalne politike na gospodarski rast u novim državama članicama Europske unije. Pregled empirijske literature pokazuje da su, do sada, ove države tek sporadično uključivane u studije rasta. Uzroke tome valja tražiti u nedostatku podataka i/ili njihovoj nedovoljnoj kvaliteti. Međutim, s vremenom kvaliteta i dostupnost podataka je značajno poboljšana. S druge strane, ove države već nekoliko godina funkcioniraju unutar istog institucionalnog i pravnog okvira kao i razvijene države članice EU, što zahtijeva produbljivanje spoznaja o utjecaju fiskalne politike na njihovu putanju rasta. Cilj je ovoga članaka popuniti taj jaz empirijskom analizom veze između fiskalne politike i rasta koja se provodi na panel podacima za razdoblje 1999.-20Io. i uzorak koji čine nove države članice EU i Hrvatska.

Empirijska analiza se temelji na dosljednoj primjeni državnog proračunskog ograničenja u kontekstu statičke i dinamičke analize panel podataka. Sveobuhvatna analiza fiskalne politike i gospodarskog rasta zahtijevala bi istodobno ispitivanje utjecaja svih fiskalnih varijabli - prihoda, rashoda i fiskalnog salda (Kneller et al., 1999). Međutim, fiskalne varijable su podložne proračunskom ograničenju prema kojem je suma ukupnih prihoda, rashoda i fiskalnog salda jednaka nuli što implicira pojavu savršene kolinearnosti. Kako bi se izbjegla savršena kolinearnost Kneller et al. (1999) sugeriraju da se iz analize izostavi fiskalna varijabla koja je neutralna u odnosu na rast. Izostavljena fiskalna varijabla se tada može smatrati implicitnim izvorom financiranja fiskalnih varijabli koje su uključene u empirijsku analizu.

U ovom se članku također analiziraju eventualni učinci na rast koji proizlaze iz hirovitosti državnih investicija. Dalić (2013) je pokazala da državni rashodi u novim državama članicama djeluju prociklički pri čemu posebno snažno prociklično ponašanje pokazuju kapitalni rashodi. Promjena stope rasta outputa izaziva istosmjernu i iznad proporcionalnu reakciju državnih investicija ukazujući na moguću visoku hirovitost $\mathrm{u}$ kretanju investicijskih rashoda. Postavlja se stoga pitanje ima li visoka hirovitost državnih investicija eventualne vlastite učinke na rast povrh onih koje proizlaze iz date razine $\mathrm{i}$ strukture državnih investicijskih rashoda. Empirijska analiza povezanosti između hirovitosti kapitalnih izdataka i rasta je posebno zanimljiva kod novih članica EU s obzirom da se radi o skupini zemalja s relativno visokim kapitalnim izdacima.

Članak je podijeljen u pet poglavlja. Nakon uvodnog dijela prikazani su ključni doprinosi teorijske i empirijske literature o utjecaju fiskalne politike na rast. U trećem poglavlju su opisani podaci i strategija empirijske analize. Četvrto poglavlje donosi rezultate empirijske analize dok se analiza robustnosti dobivenih rezultata prikazuje u petom poglavlju. Zaključci se iznose u posljednjem, šestom poglavlju.

\section{Preglete literatiure}

Endogeni modeli rasta (Lucas, 1998; Romer, I990; Aghion i Howitt, 1992) su oblikovali teorijsku osnovu za proučavanje utjecaja fiskalne politike na dugoročnu stopu rasta. Polazeći upravo od zaključaka endogenih modela rasta, Barro (1990) je prvi formulirao mehanizam kojim fiskalna politika može utjecati na razinu outputa, ali i njegovu ravnotežnu stopu rasta.

Barro (1990) je pokazao da utjecaj fiskalne politike na rast proizlazi iz tijeka usluga koje država osigurava privatnom sektoru i definirao razliku između distorzivnog i nedistorzivnog oporezivanja te produktivnih i neproduktivnih rashoda. Distorzivnim porezima smatraju se oni koji utječu na odluke 
domaćinstava i poduzeća o štednji odnosno investicijama u fizički i ljudski kapital. Nasuprot tome, nedistorzivni porezi ne utječu na odluke o štednji i investicijama.

Državne rashode je moguće klasificirati prema njihovu doprinosu privatnoj proizvodnji i produktivnosti ukupnog kapitala (Zagler i Dürnecker, 2003). Rashodne kategorije koje utječu na produktivnost privatnog kapitala i/ili zalihu ukupnog kapitala se smatraju produktivnim rashodima. Primjeri su rashodi za obrazovanje (Lucas, 1988), zdravstvo (Bloom, Canning i Sevilla, 200I), javnu infrastrukturu (Barro, 1990; Aschauer, 1988); istraživanje i razvoj (Romer, 1990) i zaštitu vlasničkih prava (La Porta et al., 1996). Kategorije rashoda koje ne utječu na produktivnost privatnog kapitala se smatraju neproduktivnim rashodima. Razvrstavanje pojedinih rashodnih kategorija u neproduktivne rashoda ne znači da su te rashodne kategorije nepotrebne već da je njihove potencijalne učinke na ukupno blagostanje društva suviše teško procijeniti na način pogodan za uključivanje u analizu rasta. Međutim, financiranje neproduktivnih rashoda zahtijeva nametanje poreza koji onda imaju vlastite učinke na rast.

Općenito, javni rashodi, bilo produktivni ili neproduktivni, umanjuju resurse raspoložive za potencijalno produktivniju privatnu upotrebu zbog čega produktivnost javnih rashoda ovisi i o stupnju komplementarnosti/supstitucije s privatnim izdacima (Irmen i Kuehnel, 2009). Sukladno tome, sveukupni učinak fiskalne politike na rast je jednak neto rezultatu koji proizlazi iz pozitivnih i negativnih učinaka njezinih instrumenata (poreza, poreznih stopa i rashoda) na produktivnost ukupnog kapitala i povrate od ulaganja u ljudski i fizički kapital (Zagler i Dürnecker, 2003).

S druge strane, utjecaj pojedinih kategorija rashoda na rast ovisi također i o makroekonomskim učincima fiskalne politike i njezinim implikacijama na održivost javnih financija. U uvjetima Rikardijanske ekvivalencije, učinak fiskalne ekspanzije na rast može biti neutralan zbog proporcionalnog snižavanja privatne potrošnje (Barro, 1979). Štoviše, pri visokoj razini javnog duga permanentno povećanje državnih rashoda može imati negativne učinke na rast (Blanchard, I99o; Alesina et al., 2002; Alesina i Ardagna, 2009). Kontinuirano povećanje fiskalnog deficita i visok javni dug mogu, čak i u odsustvu Rikardijanske ekvivalencije, imati negativne posljedice na rast jer financiranje deficita umanjuje resurse raspoložive za akumulaciju kapitala u privatnom sektoru (Zagler i Dürnecker, 2003). Štetni učinci fiskalnog deficita i duga mogu se dodatno povećati ukoliko se zaduženje koristi za financiranje manje produktivnih kategorija rashoda.

U empirijskoj literaturi ove su hipoteze provjeravane korištenjem različitih klasifikacija državnih prihoda i rashoda uz različite načine razrješavanja linearne ovisnosti između prihoda, rashoda i fiskalnog salda. Devarajan, Swaroop i Zou (1996) su zaključili da produktivnost različitih kategorija rashoda ovisi o njihovu udjelu u ukupnim rashodima odnosno da produktivnost pojedine rashodne kategorije ovisi o njezinoj relativnoj veličini. Općenito, javne investicije su prepoznate kao produktivna odrednica rasta (Aschauer, 1986; Easterly i Rebelo, 1993; Canning i Pedroni, 2004). Postoje međutim i dokazi koji pobijaju takve rezultate i upozoravaju i na moguću neutralnost javnih investicija u odnosu na rast (Afonso i Furcheri, 2008). U kontekstu europskih država dokazi o pozitivnim učincima obrazovanja na rast upućuju na važnost tercijarnog obrazovanja (Aghion, 2009).

Empirijska istraživanja koja su relativno starijeg datuma se najčešće usmjeravaju na analizu pojedinih fiskalnih varijabli npr. rashoda ili samo nekih kategorija rashoda. Međutim, Kneller et al. (I999) naglašavaju da analiza utjecaja fiskalne politike na rast mora uključiti sve fiskalne varijable kako bi se izbjegao problem ispuštenih varijabli. Međutim, u tom se slučaju pojavljuje problem savršene 
kolinearnosti s obzirom da postoji linearna veza između varijabli prihoda, rashoda i fiskalnog salda. Kneller et al. (1999) sugeriraju, stoga, da se iz regresija rasta isključe varijable sa zanemarivim učincima na rast koje se onda mogu tretirati kao implicitni izvor financiranja. Koristeći ovaj pristup Kneller et al. (I999) su pokazali da povećanje produktivnih rashoda koje je financirano nedistorzivnim porezima i snižavanjem neproduktivnih rashoda ima pozitivne učinke na rast. S duge strane, povećanje javnih investicijskih rashoda ima negativne učinke na rast ako je financirano distorzivnim porezima. Bleaney et al. (200I) su potvrdili ove rezultate i dodatno pokazali da fiskalni suficit ostvaren povećanjem nedistorzivnih poreza i snižavanjem neproduktivnih rashoda ima pozitivne učinke na rast.

Robustnost ovih rezultata provjeravali su Gemmell et al. (20II) i za uzorak razvijenih država članica OECD-a potvrdili da distorzivni porezi imaju negativne učinke na rast dok je učinak produktivnih rashoda na rast pozitivan.

Novija istraživanja naglašavaju povezanost makroekonomske hirovitosti i rasta kao dodatan kanal kroz koji fiskalna politika utječe na rast. Fatas i Mihov (2003) tvrde da je hirovitost državnih rashoda glavni uzrok hirovitosti poslovnog ciklusa koja onda negativno djeluje na rast (Hnatovska i Loayza, 2004; Aghion i Banerjee, 2005). Fatas i Mihov (2009) također iznose dokaze koji pokazuju da hirovitost javnih rashoda ima vlastite učinke na rast koji su nezavisni od utjecaja hirovitosti poslovnog ciklusa na putanju rasta. Afonso i Furceri (2008) potvrđuju štetne učinke hirovitosti javnih rashoda na rast $\mathrm{u}$ razvijenim članicama EU (EU-I5).

Teorijski izvori i empirijska istraživanja na koja se oslanja ovaj članak usmjerena su prema istraživanju učinaka fiskalne politike na ponašanje privatnog sektora i formiranje ljudskog i fizičkog kapitala. Pokazuje se da fiskalna politika utječe na gospodarski rast kako razinom oporezivanja i državnih rashoda tako i hirovitošću javnih rashoda. Štoviše, utjecaj fiskalne politike na rast ovisi i o načinu na koje se ostvaruje prilagodba u visini oporezivanja i rashoda odnosno o načinu na koji se snižavanje poreza i/ili povećanje produktivnih rashoda financira.

\section{Metodologija I PODAGI}

Utjecaj fiskalne politike na rast se ispituje regresijskom analizom veze godišnje stope rasta BDP-a i skupa zavisnih varijabli koji je sastavljen od nefiskalnih i fiskalnih varijabli. Na panel podacima je, stoga, ocijenjen model sljedećeg oblika (supskripti označavaju državui za godinu $t$ ):

$$
\mathrm{g}_{\mathrm{i}, \mathrm{t}}=\propto+\sum_{\mathrm{k}=\mathrm{I}}^{k} \beta_{\mathrm{k}} \mathrm{Y}_{\mathrm{ik}, \mathrm{t}}+\sum_{\mathrm{j}=\mathrm{I}}^{\mathrm{m}} \mathrm{Yj}_{\mathrm{j}} \mathrm{X}_{\mathrm{ij}, \mathrm{t}}+u_{i, t}
$$

gdje

$g_{i, t}$ označava stopu rasta BDP-a za državu $i(\mathrm{i}=\mathrm{I} . . . \mathrm{I} 3)$ u godini $t(\mathrm{t}=\mathrm{I} . . . \mathrm{I} 2)$

$Y_{i k, t}$ Označava skup $k$ nefiskalnih varijabli $(\mathrm{k}=\mathrm{I} . . .5)$

$X_{i j, t}$ označava skup $m$ fiskalnih varijabli $(\mathrm{m}=$ I...I3) koje također uključuju varijable koje mjere hirovitost državnih investicijskih rashoda.

Sve fiskalne i nefiskalne varijable su transformirane u logaritamski oblik.

Izbor nefiskalnih zavisnih varijabli sukladan je standardnom pristupu u literaturi (Levine i Renelt, 1992) i uključuje inicijalnu razinu BDP-a per capita, inflaciju, prosječnu stopu rasta radne snage, udio investicija u BDP-u i otvorenost (definicija varijabli je dana u prilogu). Inflacija se uključuje $s$ vremenskim pomakom od jedne godine, jer promjene $u$ indirektnim porezima utječu na kretanje inflacije u tekućem razdoblju. 
Očekivani predznak koeficijenta uz inicijalnu razinu BDP-a per capita je negativan s obzirom da manje razvijene države obično rastu brže od razvijenih. Očekivani predznak koeficijenta uz varijablu inflacije je također negativan jer visoka inflacija ima negativne učinke na dugoročne investicije, a time i na rast (Barro, 1990). Stopa rasta radne snage i udio investicija u BDP-u utječu na funkciju proizvodnje jer određuju ponudu rada i fizičkog kapitala zbog čega je očekivani predznak ovih varijabli pozitivan. Međutim, očekivane učinke otvorenosti na rast nije moguće unaprijed sasvim jednoznačno utvrditi. Ekonomije koje imaju visok stupanj otvorenosti mogu rasti brže od manje otvorenih, ako postoji dovoljno visoka eksterna potražnja. Međutim, otvorenije ekonomije su također izloženije eksternim šokovima. Predznak koeficijenta uz varijablu otvorenosti je stoga potrebno empirijski utvrditi na raspoloživom uzorku.

Skup fiskalnih varijabli uključuje:

- varijablu koja mjeri hirovitost državnih investicijskih rashoda kako je definirano jednadžbom (2) i uključena u regresiju rasta s vremenskim pomakom od jedne godine;

- varijable koje mjere ukupnu državnu aktivnost tj. varijable ukupnih prihoda, rashoda i fiskalnog salda;

- varijable koje mjere različite individualne komponente prihoda i rashoda.

Sve fiskalne varijable su definirane kao udjeli u BDP-u, odnose se na opću državu i transformirane su u logaritamski oblik (detaljan opis i definicija varijabli prikazana je u prilogu).

Hirovitost državnih investicijskih rashoda se mjeri kvadratom odstupanja godišnje razine državnih investicija od prosječne vrijednosti državnih investicijskih rashoda za cijeli uzorak.

$$
\text { VOL_INV } V_{i, t}=\left(G O V \_I N V_{i, t}-\left(\frac{I}{T} \sum_{t=I}^{T} G O V_{-} I N V_{i, t}\right)\right)^{2}
$$

Gdje GOV_INV ${ }_{i, t}$ označava udio državnih investicijskih rashoda u BDP-u u državi $i$ za godinu $t$. Potrebno je istaknuti da ovako definirana mjera hirovitosti ne razlikuje povećanja i smanjivanja državnih investicijskih rashoda, već ukazuje isključivo na intenzitet promjene bez obzira na njezin smjer. Međutim, očekivani predznak koeficijenta uz varijablu VOL_INV je negativan jer nagle promjene $u$ razini državnih investicijskih rashoda, bez obzira na smjer tih promjena, mogu stvoriti nesigurnost $u$ pogledu veličine inputa koje država osigurava privatnoj proizvodnji. Dodatno, hirovitost $\mathrm{u}$ formiranju javnog kapitala može također izazvati pogrešno strateško pozicioniranje privatne proizvodnje i rezultirati u neadekvatnom dimenzioniranju proizvodnih kapaciteta privatnog sektora koje onda nije moguće brzo mijenjati. Ova je varijabla stoga u regresiju rasta uključena s pomakom od jedne godine.

Ispitivanje utjecaja fiskalne politike na rast zahtijeva razlikovanje distorzivnih i nedistorzivnih poreza s jedne, te produktivnih i neproduktivnih rashoda s druge strane. Način na koji su individualne komponente prihoda i rashoda razvrstane $\mathrm{u}$ ove kategorije prikazan je $\mathrm{u}$ tabeli I. Iako su sve vrste poreza $u$ određenoj mjeri distorzivne, $u$ ovom se radu relevantnim distorzijama smatraju one koje su povezane s donošenjem odluka o štednji i investicijama. Porezi na dohodak i dobit te socijalni doprinosi se stoga smatraju distorzivnim porezima, jer uvode porezni klin koji može promijeniti motive za akumulaciju fizičkog i ljudskog kapitala i time negativno djelovati na rast (Zagler i Dürnecker, 2003). Porezi na dobra i usluge se smatraju nedistorzivnima - ili barem manje distorzivnima - jer ne utječu na izbor između potrošnje i štednje u različitim vremenskim trenutcima (Bleaney et al., 200I). 


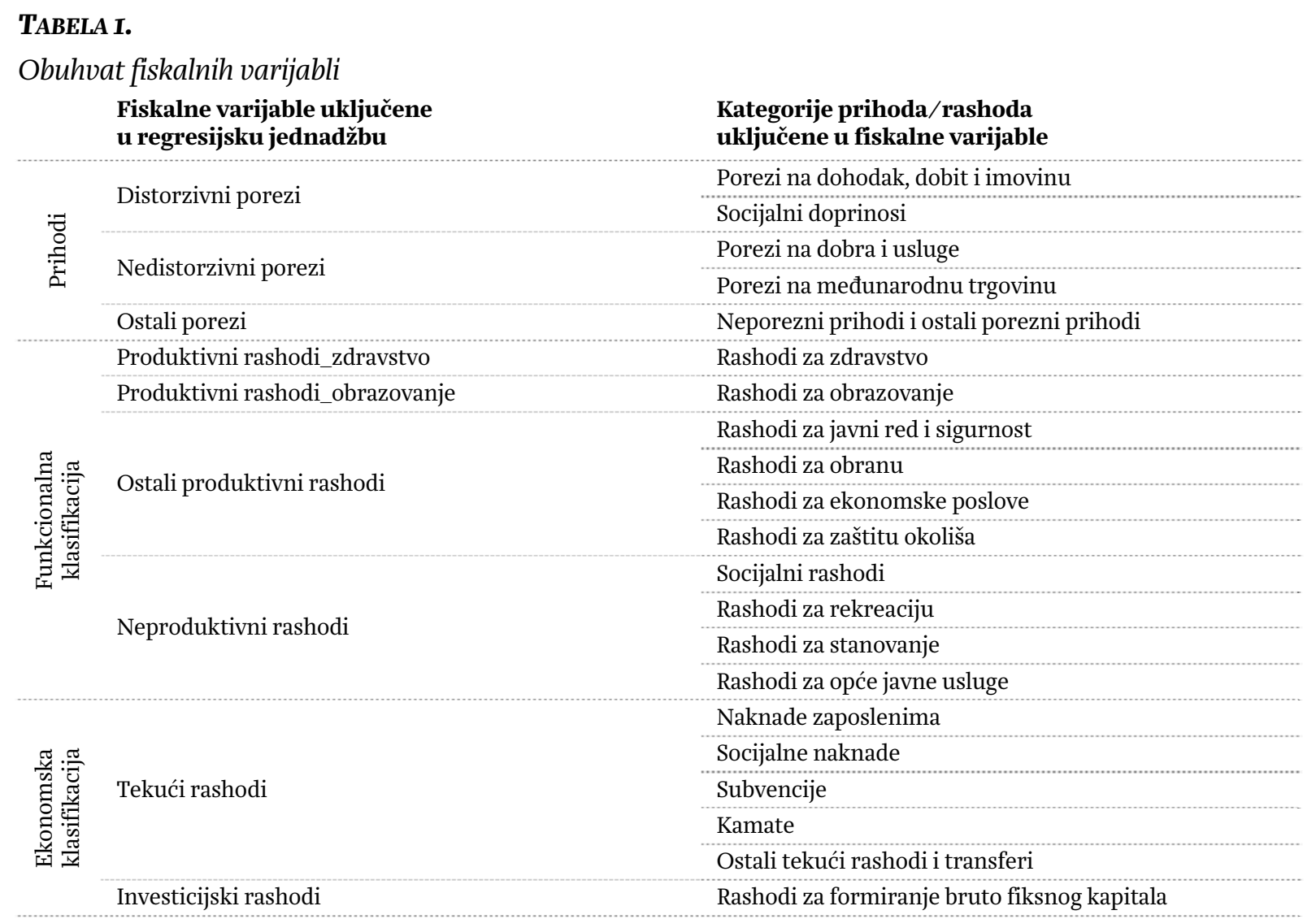

Za razliku od poreza čije razvrstavanje u distorzivne i nedistorzivne ne izaziva veće dvojbe, razvrstavanje individualnih kategorija rashoda u produktivne i neproduktivne otvara određena pitanja. Državni rashodi se statistički prate prema funkcionalnoj i prema ekonomskoj klasifikaciji, međutim, kriteriji niti jedne od tih klasifikacija nisu u potpunosti prilagođeni zahtjevima analize rasta. Zbog toga nije moguće jednoznačno i precizno razlikovanje produktivnih i neproduktivnih rashoda. Na primjer, opće je prihvaćeno da se rashodi za obrazovanje i zdravstvo smatraju produktivnim rashodima tj. rashodima s pozitivnim učincima na rast. Međutim, funkcionalna kategorija rashoda za ekonomske usluge sadrži teoretski produktivne rashode (npr. izdatke za transport i komunikacije), ali i neproduktivne rashode kao što su, na primjer, subvencije državnim poduzećima koje posluju s gubitkom. Proizlazi da funkcionalna klasifikacija ne omogućuje jednoznačnu identifikaciju produktivnih rashoda. S druge strane, veza između očekivano produktivnih državnih investicija i rasta se može preciznije ispitivati korištenjem ekonomske klasifikacije čiji je nedostatak nemogućnost preciznog identificiranja ostalih vrsta potencijalno produktivnih rashoda. Ove su nedoumice općenito prisutne u literaturi koja se bavi empirijskim istraživanjem povezanosti fiskalne politike i rasta, pa postoje primjeri istraživanja koja se temelje na funkcionalnoj klasifikaciji (Kneller et al., 1999; Gemmell et al., 20II; Adam i Bevan, 2005) ali i brojne empirijske studije koje koriste ekonomsku klasifikaciju (Gupta et al., 2002; de Avila i Strauch, 2003; Afonso i Furceri, 2008).

U ovom se članku navedeni problemi pokušavaju razriješiti usporednim korištenjem obje klasifikacije. Model iz izraza (I) se prvo ocjenjuje za skup fiskalnih varijabli u kojem su varijable rashoda definirane temeljem funkcionalne klasifikacije, a nakon toga se isti model ocjenjuje za varijable rashoda definirane temeljem ekonomske klasifikacije. Ovako dobiveni rezultati nisu međusobno isključivi već komplementarni. Na primjer, pozitivni učinci na rast državnih investicija (koji se izvode iz ekonomske 
klasifikacije) nisu u suprotnosti s pozitivnim učincima rashoda za obrazovanje (koji se izvode iz funkcionalne klasifikacije), jer signaliziraju da kvalitetnija fizička infrastruktura - uključujući i onu u sektoru obrazovanja - može osnažiti rast.

Kao što je navedeno u tabeli I rashodi za obrazovanje i zdravstvo se smatraju produktivnima jer su povezani s akumulacijom ljudskog kapitala. Rashodi za ekonomske usluge se klasificiraju kao produktivni jer, unatoč spoznaji da sadrže i neke neproduktivne izdatke, njihovu najznačajniju sastavnicu čine rashodi za transport i komunikacije čiji su očekivani učinci na rast pozitivni (Easterly i Rebelo, 1993). Rashodi za obranu i rashodi za javni red i sigurnost se smatraju produktivnima, jer osiguravaju poštivanje zakona, pridonose sigurnosti investitora i stabilnosti vlasničkih prava što su sve činitelji s pozitivnim učincima na rast (Barro, 1990).

Neproduktivni rashodi uključuju izdatke za socijalnu sigurnost, stanovanje, rekreaciju i javnu administraciju stoga što ne djeluju direktno na formiranje privatnog kapitala i njegovu produktivnost. Međutim, potrebno je imati na umu da se kvaliteta i efikasnost javne administracije odražava u kvaliteti institucija, a upravo njih institucionalna ekonomika prepoznaje kao bitnu odrednicu rasta (Acemoglu, 20I2). Postoje stoga određeni argumenti za uključivanje rashoda za opće javne usluge u kategoriju produktivnih rashoda zbog čega se $u$ analizi robustnosti (peto poglavlje) koristi alternativna definicija varijable "ostali produktivni rashodi” koja uključuje rashode za opće javne usluge.

Pri korištenju ekonomske klasifikacije ukupni rashodi se dijele na tekuće i investicijske. Investicijski rashodi se smatraju produktivnima, dok se tekući smatraju neproduktivnima, jer njihovu najznačajniju sastavnicu čine neproduktivne kategorije kao što su rashodi za socijalne izdatke, subvencije i kamate. Uzimajući u obzir argumente institucionalne ekonomike i u ovom bi se slučaju moglo postaviti pitanje ispravnosti razvrstavanja naknada zaposlenima $\mathrm{u}$ kategoriju neproduktivnih tekućih rashoda. Međutim, u analizi robustnosti ova mogućnost nije testirana.

Ocjena modela iz izraza (I) se temelji na pristupu koji su predložili Kneller et al. (1999) i Bleaney et al. (200I) i koji su pokazali da veza fiskalne politike i rasta ovisi o načinu uključivanja proračunskog ograničenja. Kao što je već naglašeno, ovaj pristup zahtijeva ispuštanje barem jedne varijable koja sačinjava proračunsko ograničenje iz regresijske jednadžbe kako bi se izbjegao problem savršene kolinearnosti. Ispuštena varijabla tada predstavlja implicitni izvor financiranja jedinične promjene relevantnih fiskalnih varijabli uključenih u ocijenjenu regresijsku jednadžbu. Kneller et al. (1999) su pokazali da se veličina koeficijenta uz fiskalne varijable uključene u regresiju mijenja ovisno o vrsti fiskalne varijable koja je ispuštena iz regresije. Drugim riječima, učinak određenog instrumenta fiskalne politike na rast se može mijenjati ovisno o načinu na koji se promjena tog instrumenta fiskalne politike financira.

Kneller et al. (1999) su predložili ispuštanje onih fiskalnih varijabli za koje ekonomska teorija pokazuje da nemaju direktnog utjecaja na proizvodnu funkciju. Sukladno tome, kandidati za ispuštene fiskalne varijable su neproduktivni rashodi, nedistorzivni porezi odnosno obje varijable istodobno. Štoviše, ako su ove varijable stvarno neutralne $u$ odnosu na rast tada bi u slučaju njihove uključenosti u regresiju pripadajući koeficijenti trebali biti nula. Međutim, potrebno je također imati na umu i upozorenje koje ističu Adam i Bevan (2005). Oni podsjećaju da heterogenost država koje formiraju uzorak na kojem se provodi regresijska analiza rasta može onemogućiti identificiranje bilo koje pojedinačne kategorije prihoda ili rashoda koja bi bila neutralna u svim državama. Sukladno tome, u ovakvom tipu regresije bi se ocjene koeficijenata trebale interpretirati kao učinak određene fiskalne varijable koji preostaje 
nakon učinka ispuštenih varijabli (neto efekt nakon učinka ispuštenih varijabli). Dodatno, Gemmell (200I) ističe da pri visokom udjelu poreza i rashoda u BDP-u svako daljnje povećanje poreza može imati negativne učinke na rast čak i ako su svi rashodi produktivni.

Uzorak država na čijim se podacima provodi ovo istraživanje obuhvaća nove članice EU i Hrvatsku tijekom razdoblja 1999--2000. Ove su države tek sporadično uključivane u dosadašnja istraživanja u prvom redu zbog nepostojanja podataka ili njihove niske kvalitete uzrokovane strukturnim lomovima i dubokim ekonomskim promjenama kroz koje su ove države prolazile tijekom 199o-ih. Kao početna godina uzorka odabrana je 1999. jer je te godine većina država obuhvaćenih uzorkom otpočela pregovore o članstvu u EU zbog čega se postepeno počela poboljšavati kvaliteta i usporedivost njihovih podataka. Hrvatska je uključena u uzorak jer je u promatranom razdoblju dovršila prilagodbu EU standardima. Izvori podataka su Eurostat, WDI baza Svjetske banke (za neke kontrolne varijable) i nacionalni izvori podataka za Hrvatsku.

\section{EMPIRIJSKI REZULTATI}

\section{I. DESKRIPTIVNA STATISTIKA I KORELAGIJE U PAROVIMA}

Tabela 2 prikazuje deskriptivnu statistiku za sve regresijske varijable i potvrđuje primjerenu varijabilnost korištenih serija podataka. Prosječna stopa rasta za cijeli uzorak iznosi 3,4\% dok prosječna veličina ukupnih državnih rashoda, mjerena njihovim udjelom u BDP-u, iznosi 4I,6\%. Prosječni fiskalni saldo za cjelokupni uzorak je deficit od 3,4\% BDP-a. U svim državama obuhvaćenim uzorkom neproduktivni rashodi su u prosjeku veći od produktivnih, dok su istovremeno prihodi od distorzivnih poreza veći nego prihodi od nedistorzivnih.

\section{TABELA 2.}

\section{Deskriptivna statistika}

\begin{tabular}{|c|c|c|c|c|c|c|}
\hline \multirow[b]{2}{*}{ Stopa rasta outputa } & \multirow{2}{*}{$\begin{array}{c}\text { Prosjek } \\
3,4\end{array}$} & \multirow{2}{*}{$\begin{array}{c}\begin{array}{r}\text { Stand. } \\
\text { devijacija }\end{array} \\
4,5\end{array}$} & \multicolumn{2}{|c|}{ Maksimum/Država } & \multicolumn{2}{|c|}{ Minimum/Država } \\
\hline & & & II,5 & Latvija (2006) & $-\mathrm{I} 7,7$ & Latvija (2009) \\
\hline BDP per capita, cons. EUR & $6.812,2$ & $3.866, \mathrm{I}$ & I6.740,8 & Cipar (2008) & I.6I2,9 & Bugarska (I999) \\
\hline Stopa investicija, \% BDP-a & 23,5 & 4,3 & 34,9 & Estonija (2006) & $\mathrm{I} 4,2$ & Malta (2000) \\
\hline Otvorenost, \% BDP-a & $\mathrm{II} 7,2$ & 32,0 & $\mathrm{I} 94,8$ & Malta (2000) & 53,2 & Rumunjska (20IO) \\
\hline Inflacija, ch & $5, \mathrm{I}$ & 6,2 & 45,8 & Rumunjska (I999) & $-\mathrm{I}, \mathrm{I}$ & Litva (2003) \\
\hline Stopa rasta radne snage, $\mathrm{u} \%$ & $-0,06$ & $\mathrm{I}, 48$ & 4,3 & Slovenija (2004) & $-8,8$ & Rumunjska (2002) \\
\hline Ukupni prihodi, \% BDP-a & 38,2 & 3,7 & 46,9 & Mađarska (20IO) & $3 \mathrm{I}, 7$ & Litva (2004) \\
\hline Ukupni rashodi, \% BDP-a & 41,6 & 4,8 & 52,2 & Mađarska (2006) & 33,0 & Litva (2003) \\
\hline Fiskalni saldo, \% BDP-a & $-3,4$ & 2,8 & 3,4 & Cipar (2007) & $-\mathrm{I} 2,3$ & Slovačka (200o) \\
\hline Distorzivni porezi, \% BDP-a & 20,3 & 2,7 & 25,8 & Cipar (2007) & 13,2 & Bugarska (20Io) \\
\hline Nedistorzivni porezi, \% BDP-a & I3,6 & 2,2 & $I 8,6$ & Hrvatska (200o) & IO,I & Slovačka (2OIO) \\
\hline Ostali prihodi, \% BDP-a & $5, \mathrm{I}$ & $\mathrm{I}, 2$ & IO,4 & Bugarska (I999) & 3,2 & Rumunjska (2000) \\
\hline $\begin{array}{l}\text { Produkt. rashodi_obrazovanje, } \\
\% \text { BDP-a }\end{array}$ & 5,2 & $\mathrm{I}, \mathrm{I}$ & 7,5 & Cipar (20I0) & 3,3 & Hrvatska (2006) \\
\hline $\begin{array}{l}\text { Produkt. rashodi_zdravstvo, } \\
\% \text { BDP-a }\end{array}$ & 5,0 & $\mathrm{I}, 3$ & 7,8 & Češka (2OIO) & 2,5 & Bugarska (200I) \\
\hline $\begin{array}{l}\text { Ostali produktivni rashodi, } \\
\text { \% BDP-a }\end{array}$ & 9,7 & I,8 & $\mathrm{I} 7,4$ & Slovačka (200o) & 6,4 & Poljska (200o) \\
\hline Neproduktivni rashodi, \% BDP-a & $2 \mathrm{I}, 6$ & 3,9 & $3 \mathrm{I}, 6$ & Mađarska (2009) & I4,6 & Estonija (2006) \\
\hline Državne investicije, \% BDP-a & 3,6 & $\mathrm{I}, \mathrm{I}$ & 6,8 & Češka (2003) & I,I & Latvija (2OOI) \\
\hline Tekući rashodi, \% BDP-a & 36,5 & 4,4 & 47,0 & Mađarska (2009) & 27,8 & Estonija $(2007)$ \\
\hline Varijabilnost državnih investicija & 0,87 & $\mathrm{I}, 3 \mathrm{O}$ & $\mathrm{O}, \mathrm{O}$ & Mađarska (2004) & 7,I & Rumunjska (I999) \\
\hline
\end{tabular}


Tabela 3 prikazuje korelacije $u$ parovima za sve varijable uključene $u$ regresijsku analizu. Poboljšanje fiskalnog salda (tj. povećanje suficita ili snižavanje deficita) je snažno i pozitivno korelirano s rastom realnog BDP-a, dok su ukupni prihodi i rashodi isto kao i neke od njihovih dezagregiranih komponenti negativno povezani s rastom. Sukladno očekivanjima, različite komponente prihoda i rashoda su međusobno visoko korelirane što potvrđuje važnost odabranog pristupa u kojem se problem savršene kolinearnosti razrješava ispuštanjem fiskalnih varijabli za koje se očekuje da bi trebale biti neutralne u odnosu na rast. Na ovaj se način djelomično umanjuje i problem visoke korelacije između određenih fiskalnih varijabli. 


\section{TABELA 3.}

Korelacije u parovima

$$
\text { แก } 1 \text { | }
$$

Realna stopa rasta BDP-a, \%

BDP per capita, EUR

$\mathrm{I}, \mathrm{OO}$

Investicije

Otvorenost

Inflacija

Stopa rasta radne snage

Fiskalni saldo

Ukupni rashodi

Ukupni prihodi

Rashodi za obrazovanje

Rashodi za zdravstvo

Ostali produktivni rashodi

Neproduktivni rashodi

Distorzivni porezi

Nedistorzivni porezi $\begin{array}{rrr}-0,08 \quad I, 00 \\ 0,0,29 & -0,17 * 2\end{array}$

Državne investicij

Tekući rashodi

Hirovitost državnih

investicija

$\begin{array}{lll}0,29^{* * *} & -0,17^{* *} & \mathrm{I}, \mathrm{OO}\end{array}$

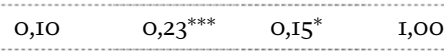

$\begin{array}{lllll}0,07 & -0,05 & -0,02 & -0,35^{* * *} & \mathrm{I}, \mathrm{OO}\end{array}$

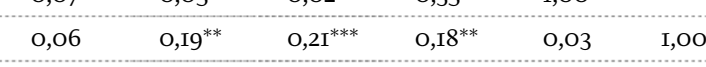

$\begin{array}{llllllll}0,52^{* * *} & -0,05 & 0,34^{* * *} & 0,05 & 0,09 & 0,05 & \text { I,OO }\end{array}$

$\begin{array}{llllllll}-0,44^{* * *} & 0,33^{* * *} & -0,26^{* * *} & 0,08 & -0,06 & 0,07 & -0,63^{* * *} & \mathrm{I}, \mathrm{OO}\end{array}$

$\begin{array}{lllllllll}-0,17^{* *} & 0,36^{* * *} & -0,08 & 0, \mathrm{I} 4 & -\mathrm{O}, \mathrm{OI} & 0, \mathrm{I} 3 & -0,05 & 0,8 \mathrm{O}^{* * *} & \mathrm{I}, \mathrm{OO}\end{array}$

$\begin{array}{lllllllllll}-0, \mathrm{I3} & \mathrm{O}, 5^{* * *} & -\mathrm{O}, \mathrm{IO} & \mathrm{O}, \mathrm{I} 4 & \mathrm{O}, \mathrm{IO} & \mathrm{O}, \mathrm{II} & \mathrm{O}, \mathrm{O} 2 & \mathrm{O}, \mathrm{I} 4^{*} & \mathrm{O}, 2 \mathrm{O}^{* *} & \mathrm{I}, \mathrm{OO}\end{array}$

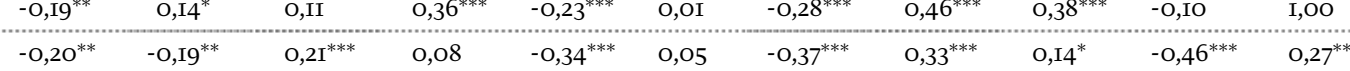

$\begin{array}{llllllllllllll}-0,34^{* * *} & 0,28^{* * *} & -0,44^{* * *} & -0,09 & 0, \mathrm{I}^{*} & 0,03 & -0,52^{* * *} & 0,88^{* * *} & 0,74^{* * *} & 0, \mathrm{I} 4^{*} & 0, \mathrm{I} 5^{*} & 0,00 & \mathrm{I}, \mathrm{OO}\end{array}$

* signifikantno na razini ro\%; ** signifikantno na razini $5 \%$ *** signifikantno na razhi

* signifikantno na razin
Izvor: Izračun autorice.

$\begin{array}{lllllllllllllllllll}-0,03 & 0,24^{* * *} & -0,13^{*} & -0,09 & -0,03 & 0,15 & 0,13 & 0,43^{* * *} & 0,66^{* * *} & -0,01 & 0,00 & -0,04 & 0,54^{* * *} & -0,05\end{array}$

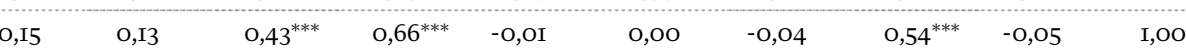

$\begin{array}{llllll}0,0,09 & 0,08 & 0,10 & 0,03 \\ 0,03 & -0,62^{* * *} & 0,98^{* * *} & 0,78^{* * *} & 0,12 & 0,46^{* * *}\end{array}$

$-0,02 \quad-0,23^{* * *} \quad 0,18^{* *} \quad-0,29^{* * *} \quad 0,05 \quad 0, I I$

$-\mathrm{O}, \mathrm{II} \quad-\mathrm{O}$,IO

$-0,22^{* *}$

$-0,13$

$-\mathrm{O}, \mathrm{I} 2$

$0,2 I^{* * *} \quad-0,15^{*}$

$-0,16^{* *}$

$\begin{array}{llll}-\mathrm{O}, \mathrm{I} 9^{* *} & \mathrm{O}, \mathrm{I} 8 & -\mathrm{O}, \mathrm{I} 4 & \mathrm{I}, \mathrm{O}\end{array}$ 
Preliminarni rezultati jednostavnih regresija dviju varijabli prikazani su grafikonom I. Grafikon prikazan u gornjem lijevom uglu prikazuje negativnu vezu veličine državnog sektora (ukupnih rashoda) i rasta dok je negativna korelacija ukupnih prihoda i rasta jasno vidljiva na grafikonu koji se nalazi u gornjem desnom uglu. Grafikon prikazan u donjem lijevom uglu ukazuje na pozitivnu vezu poboljšanja u fiskalnom saldu i rasta. Negativna korelacija hirovitosti državnih investicija i rasta naznačena je na grafikonu smještenom $\mathrm{u}$ donjem desnom uglu grafikona $\mathrm{I}$.

\section{GRAFIKON I.}

Jednostavne regresije dviju varijabli
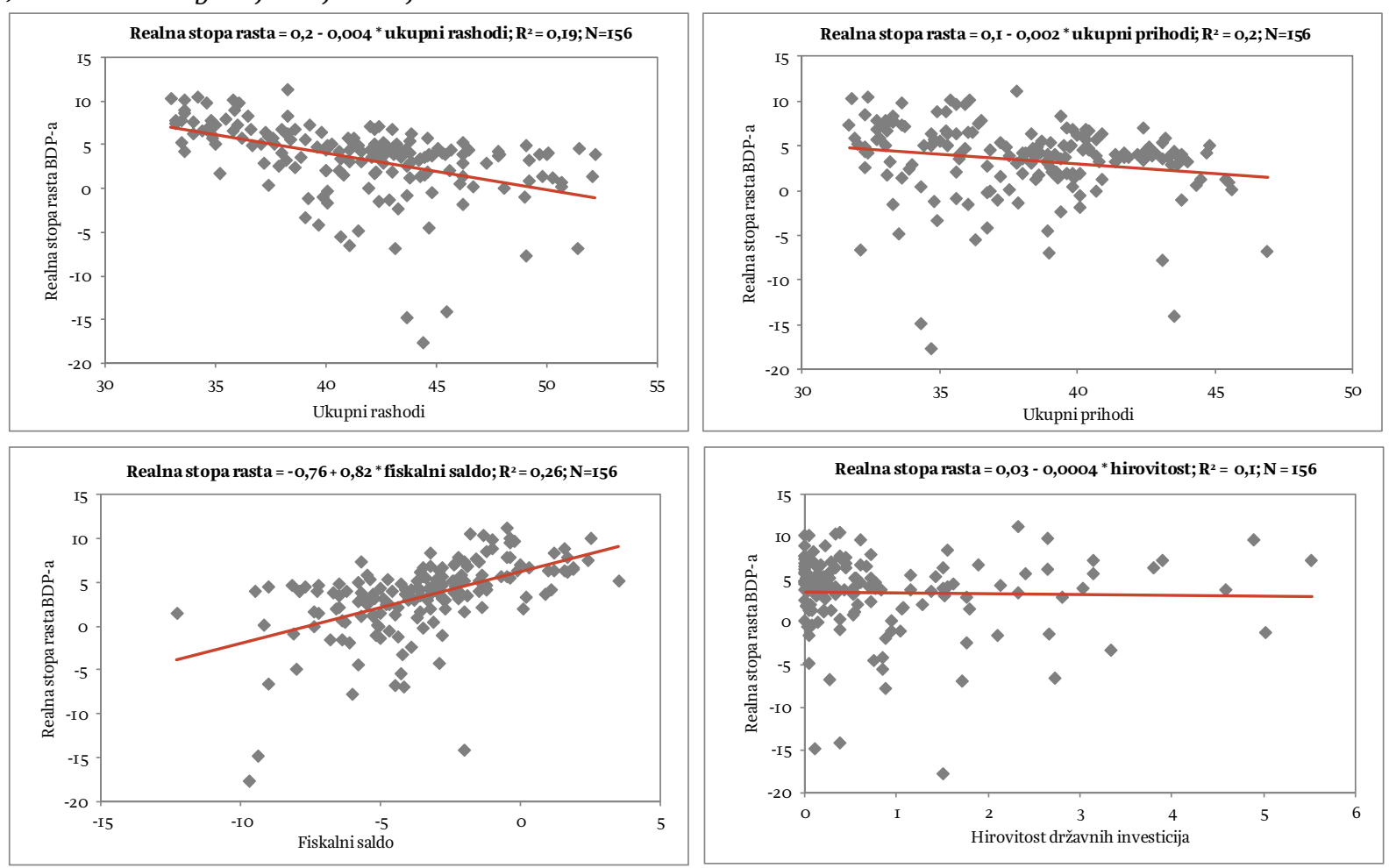

Izvor: Izračun autorice.

\subsection{OSNOVNE REGRESIJE}

Model iz izraza (I) ocijenjen je na panel podacima metodom najmanjih kvadrata s dvostranim fiksnim učinkom (eng. two-way fixed effect) i uključenom korekcijom za autokorelaciju reziduala. Hausmanov test je proveden kako bi se provjerio izbor modela s fiksnim učinkom u odnosu na model sa slučajnim učinkom. Rezultati testa potvrdili su izbor modela s fiksnim učinkom. Proveden je također i test vjerodostojnog omjera (eng. likelihood ratio test) za signifikantnost fiksnog učinka koji je potvrdio istovremeni značaj cross-section i vremenskog učinka zbog čega je odabran ocjenjivač s dvostranim fiksnim učinkom.

Osnovni rezultati prikazani su tabelom 4. Kolona $2 \mathrm{u}$ tabeli 4 prikazuje osnovne rezultate za regresiju u koju su kao objašnjavajuće varijable uključene samo nefiskalne varijable i hirovitost državnih investicija. Kolone (3) do (5) prikazuju osnovne rezultate dobivene uključivanjem fiskalnih varijabli koje mjere ukupnu državnu aktivnost.

Sve nefiskalne varijable su signifikantne i imaju očekivani predznak. Štoviše, razina signifikantnosti inflacije i stope rasta radne snage je povećana nakon uključivanja fiskalnih varijabli. Koeficijent uz 
hirovitost državnih investicija (s vremenskim pomakom), unatoč malenoj apsolutnoj vrijednosti, je negativan i statistički signifikantan u svim regresijama. Povećanje hirovitosti državnih investicija za jedan posto smanjuje stopu rasta BDP-a za prosječno o,oo3 postotna boda. Ovakav je rezultat u skladu s rezultatima Afonsa i Furceria (2008) koji nalaze negativne učinke hirovitosti državnih investicija na rast u razvijenim državama članicama EU.

\section{TABELA 4.}

Učinci ukupnih fiskalnih varijabli na rast

Metoda ocjene: metoda najmanjih kvadrata s dvostranim fiksnim učinkom

Zavisna varijabla: Stopa rasta realnog BDP-a

\begin{tabular}{|c|c|c|c|c|}
\hline & \multirow{2}{*}{$\begin{array}{l}\text { Osnovna } \\
\text { regresija }\end{array}$} & \multicolumn{3}{|c|}{ Ispuštena fiskalna varijabla } \\
\hline & & Fiskalni saldo & Ukupni prihodi & Ukupni rashodi \\
\hline $\mathbf{I}$ & 2 & 3 & 4 & 5 \\
\hline \multirow{2}{*}{ BDP per capita $(-I)$} & $-0,166^{* * *}$ & $-0,149^{* * *}$ & $-\mathrm{O}, \mathrm{I} 54^{* * *}$ & $-0,155^{* * *}$ \\
\hline & $(0,039)$ & $(0,037)$ & $(0,036)$ & $(0,037)$ \\
\hline \multirow{2}{*}{ Investicije } & $0,105^{* * *}$ & $\mathrm{O}, 082^{* * *}$ & $\mathrm{O}, 082^{* * *}$ & $0,085^{* * *}$ \\
\hline & $(\mathrm{o}, \mathrm{O} 35)$ & $(0,024)$ & $(0,024)$ & $(\mathrm{O}, \mathrm{O} 24)$ \\
\hline \multirow{2}{*}{ Stopa rasta radne snage } & O,I49 & $\mathrm{O}, \mathrm{I}^{* * *}$ & $0,193^{* *}$ & $0,197^{* *}$ \\
\hline & $(0,167)$ & $(0,090)$ & $(0,092)$ & $(\mathrm{O}, \mathrm{092})$ \\
\hline \multirow{2}{*}{ Otvorenost } & $\mathrm{O}, \mathrm{II} 8^{* * *}$ & $0,063^{* *}$ & 0,063 & $0,064^{* *}$ \\
\hline & $(0,033)$ & $(0,029)$ & $(0,029)$ & $(0,028)$ \\
\hline \multirow{2}{*}{ Inflacija (-I) } & $-0,073^{* * *}$ & $-0,123^{* * *}$ & $-\mathrm{O}, \mathrm{I}_{2} \mathrm{I}^{* * *}$ & $-\mathrm{O}, \mathrm{I}_{2} \mathrm{I}^{* * *}$ \\
\hline & $(0,053)$ & $(0,037)$ & $(0,037)$ & $(\mathrm{o}, \mathrm{O} 37)$ \\
\hline \multirow{2}{*}{ Ukupni rashodi } & & $-\mathrm{O}, 2 \mathrm{I} 7^{* * *}$ & $-\mathrm{O}, 2 \mathrm{IO}^{* * *}$ & \\
\hline & & $(0,073)$ & $(0,059)$ & \\
\hline \multirow{2}{*}{ Ukupni prihodi } & & $-\mathrm{O}, \mathrm{OII}$ & & $-0,189^{* * *}$ \\
\hline & & $(\mathrm{O}, \mathrm{IOI})$ & & $(0,054)$ \\
\hline \multirow{2}{*}{ Fiskalni saldo ${ }^{\mathrm{I}}$} & & & $-0,003$ & $0,465^{* * *}$ \\
\hline & & & $(\mathrm{O}, 24 \mathrm{I})$ & $(\mathrm{O}, \mathrm{I} 64)$ \\
\hline \multirow{2}{*}{ Hirovitost državnih investicija (-I) } & $-0,0029^{* * *}$ & $-0,0027^{* * *}$ & $-0,0027^{* *}$ & $-0,0027^{* * *}$ \\
\hline & $(0,0006)$ & $(0,0006)$ & $(0,0006)$ & $(0,0006)$ \\
\hline $\mathrm{R}^{2 \sim}$ & 0,745 & 0,825 & 0,825 & 0,822 \\
\hline Broj opažanja & 156 & 156 & 156 & 156 \\
\hline
\end{tabular}

Napomena: ***, ** $i^{*}$ označavaju signifikantnost na razini I\%, 5\% i Iо\%. Robustne standardne greške su prikazane u zagradama.

${ }^{I}$ Fiskalni saldo je definiran kao (I + fiskalni saldo/Ioo); rast varijable pokazuje poboljšanje fiskalnog salda tj. smanjivanje deficit ili povećanje suficita.

Test vjerodostojnog omjera za zajedničku signifikantnost cross-section i vremenskog fiksnog učinka: $p$-vrijednost $\chi^{2}(229,7 ; 23)=0,000$.

Hausmanov test za signifikantnost slučajnog vs. fiksnog učinka: $p$-vrijednost $\chi^{2}(193,5 ; 8)=0,000$.

Kada se fiskalni saldo ispušta iz regresije i time dopušta da se slobodno prilagođava promjenama u ukupnim prihodima i rashodima (kolona 3) koeficijent uz ukupne rashode je negativan i signifikantan dok je koeficijent uz ukupne prihode statistički nesignifikantan. Međutim, moguće je da se rezultati prikazani u koloni (3) nalaze pod utjecajem visoke korelacije ukupnih prihoda i ukupnih rashoda zbog čega su ocijenjene regresije $u$ kojima su prvo ispušteni ukupni prihodi, a nakon toga $\mathrm{i} u k u p n i$ rashodi. Ispuštanje ukupnih prihoda iz ocijenjene regresije potvrđuje negativne učinke ukupnih rashoda na rast, odnosno negativnu vezu rasta i veličine državnog sektora (kolona 4). Povećanje ukupnih rashoda za I\% (koje je implicitno financirano promjenom ukupnih prihoda) rezultira snižavanjem stope rasta za o,2I postotni bod. Negativna veza rasta i veličine državnog sektora se otkriva i ukoliko se njegova veličina mjeri i ukupnim prihodima. Kolona 5 pokazuje da povećanje ukupnih prihoda za I\% snižava realnu stopu rasta za o,I8 postotnih bodova. U ovoj je regresiji koeficijent uz fiskalni saldo pozitivan i 
signifikantan, što ukazuje da poboljšanje fiskalnog salda (tj. smanjivanje deficita) može pozitivno djelovati na rast ukoliko se financira snižavanjem ukupnih rashoda.

Rezultati prikazani u tabeli 4 pokazuju da ukupna veličina državnog sektora ima negativne učinke na rast. Ovakvi rezultati upozoravaju da se pozitivan doprinos rastu - koji može eventualno nastati od pojedinačnih produktivnih kategorija rashoda - barem jednim dijelom poništava negativnim učincima ukupne veličine državnog sektora.

Tabela 5 prikazuje rezultate za dezagregirane komponente ukupnih prihoda i rashoda. Koeficijenti uz nefiskalne varijable nisu prikazani jer je njihov predznak i signifikantnost ostao nepromijenjen. U kolonama (2) do (4) su prikazani rezultati za varijable dezagregirane temeljem funkcionalne klasifikacije rashoda dok su u kolonama (5) do (7) prikazani rezultati za varijable oblikovane korištenjem ekonomske klasifikacije. 


\section{TABELA 5.}

Učinci dezagregiranih fiskalnih varijabli na rast

Metoda ocjene: metoda najmanjih kvadrata s dvostranim fiksnim učinkom

Zavisna varijabla: stopa rasta realnog BDP-a

\begin{tabular}{|c|c|c|c|c|c|c|}
\hline \multirow[b]{2}{*}{ Ispuštena fiskalna varijabla } & \multicolumn{3}{|c|}{ Funkcionalna klasifikacija rashoda } & \multicolumn{3}{|c|}{ Ekonomska klasifikacija rashoda } \\
\hline & $\begin{array}{l}\text { Nedistorzivni } \\
\text { porezi }\end{array}$ & $\begin{array}{l}\text { Neproduktivni } \\
\text { rashodi }\end{array}$ & $\begin{array}{l}\text { Nedistorzivni porezi } \\
\text { i neproduktivni rash. }\end{array}$ & $\begin{array}{l}\text { Nedistorzivni } \\
\text { porezi }\end{array}$ & $\begin{array}{l}\text { Tekući } \\
\text { rashodi }\end{array}$ & $\begin{array}{l}\text { Nedistorzivni porezi } \\
\text { i tekući rashodi }\end{array}$ \\
\hline $\mathbf{I}$ & 2 & 3 & 4 & 5 & 6 & 7 \\
\hline \multirow{2}{*}{ Distorzivni porezi } & 0,052 & $-0,089^{* *}$ & $-0,071$ & $-0,042$ & $-0, I I 5^{* * *}$ & $-0, \operatorname{IOg}^{* *}$ \\
\hline & $(0,053)$ & $(0,038)$ & $(0,052)$ & $(0,057)$ & $(0,040)$ & $(0,049)$ \\
\hline \multirow{2}{*}{ Nedistorzivni porezi } & - & $-0, \mathrm{IOO}^{* *}$ & - & - & $-\mathrm{O}, \mathrm{IO} 4^{* * *}$ & - \\
\hline & & $(0,044)$ & & & $(0,034)$ & \\
\hline \multirow{2}{*}{ Ostali prihodi } & 0,024 & $-0,006$ & 0,006 & o,oI6 & $\mathrm{O}, \mathrm{OI7}$ & O,OI9 \\
\hline & $(0,012)$ & $(\mathrm{O}, \mathrm{OII})$ & $(0,013)$ & $(\mathrm{O}, \mathrm{OII})$ & $(0,012)$ & $(0,015)$ \\
\hline \multirow{2}{*}{ Produktivni rashodi_zdravstvo } & $-0,021$ & 0,009 & $-0,008$ & & & \\
\hline & $(0,018)$ & $(\mathrm{o}, \mathrm{OIg})$ & $(\mathrm{o}, \mathrm{OIg})$ & & & \\
\hline \multirow{2}{*}{ Produktivni rashodi_obrazovanje } & 0,002 & 0,032 & $\mathrm{O}, \mathrm{OI} 3$ & & & \\
\hline & $(0,037)$ & $(0,045)$ & $(0,05 \mathrm{I})$ & & & \\
\hline \multirow{2}{*}{ Ostali produktivni rashodi } & $-0,086^{* * *}$ & $-0,012$ & $-0,036^{* *}$ & & & \\
\hline & $(0,019)$ & $(0,018)$ & $(0,015)$ & & & \\
\hline \multirow{2}{*}{ Neproduktivni rashodi } & $-0,170^{* * *}$ & - & - & & & \\
\hline & $(0,052)$ & & & & & \\
\hline \multirow{2}{*}{ Fiskalni saldo ${ }^{\mathrm{I}}$} & $-0,193$ & $0,519^{* * *}$ & $0,360^{* *}$ & $-0,168$ & $0,6 \mathrm{OI}^{* * *}$ & $0,522^{* * *}$ \\
\hline & $(0,262)$ & $(0,167)$ & $(0,17 \mathrm{I})$ & $(0,270)$ & $(0,159)$ & $(0,177)$ \\
\hline \multirow{2}{*}{ Tekući rashodi } & & & & $-0,322^{* * *}$ & - & - \\
\hline & & & & $(0,075)$ & & \\
\hline \multirow{2}{*}{ Investicijski rashodi } & & & & $-0,002$ & $0,019^{* *}$ & $\mathrm{O}, \mathrm{OI} 3$ \\
\hline & & & & (O,OII) & $(0,009)$ & $(0,008)$ \\
\hline \multirow{2}{*}{ Hirovitost državnih investicija (-I) } & $-0,0027^{*}$ & $-0,0026^{* * *}$ & $-0,0029^{* * *}$ & $-0,0022^{* * *}$ & $-0,0022^{* * *}$ & $-0,0026^{* * *}$ \\
\hline & $(0,0006)$ & $(0,0007)$ & $(0,0006)$ & $(0,0008)$ & $(0,0007)$ & $(0,0005)$ \\
\hline $\mathrm{R}^{2 \sim}$ & 0,832 & 0,818 & 0,798 & 0,840 & 0,823 & 0,800 \\
\hline Broj opažanja & 156 & 156 & 156 & 156 & I56 & 156 \\
\hline
\end{tabular}

Napomena: ***, ** $i^{*}$ označavaju signifikantnost na razini 1\%, 5\% i Io\%. Robustne standardne greške su prikazane u zagradama.

${ }^{\mathrm{I}}$ Fiskalni saldo je definiran kao (I + fiskalni saldo/Ioo); rast varijable pokazuje poboljšanje fiskalnog salda tj. smanjivanje deficita ili povećanje suficita.

Test vjerodostojnog omjera za zajedničku signifikantnost cross-section i vremenskog fiksnog učinka: $p$-vrijednost $\chi^{2}(229,7 ; 23)=0,000$.

Hausman test za signifikantnost fiksnog učinka: $p$-value $\chi^{2}(167,6 ;$ I2) $)=0,000$. 
U regresijama koje uključuju fiskalne varijable oblikovane temeljem funkcionalne klasifikacije proračunsko ograničenje se poštuje ispuštanjem varijable prihoda i rashoda za koje teorija pretpostavlja da imaju zanemariv utjecaj na rast. Sukladno tome, nedistorzivni porezi, neproduktivni rashodi i obje ove kategorije zajedno se ispuštaju iz regresije i time pretpostavlja da su to varijable koje se slobodno prilagođavaju promjenama fiskalnih varijabli uključenih u regresiju. Drugim riječima, ispuštene varijable su implicitan izvor financiranja za promjene fiskalnih varijabli uključenih u regresiju. U regresijama u kojima se koristi ekonomska klasifikacija ispuštaju se nedistorzivni porezi, tekući rashodi i obje ove kategorije zajedno.

U svim regresijama prikazanim u tabeli 5 koeficijent uz hirovitost državnih investicija zadržava svoju veličinu, negativan predznak i signifikantnost. Analiza provedena na dezagregiranim fiskalnim varijablama potvrđuje da hirovitost državnih investicija ima vlastite negativne učinke na rast povrh učinaka koji proizlaze iz razine i strukture državnih prihoda i rashoda.

Rezultati prikazani u kolonama (2) do (4) pokazuju da dokazi o pozitivnim učincima produktivnih rashoda nisu pronađeni. Ovakvi su rezultati u određenoj mjeri suprotni teorijskim predviđanjima i to posebno onima koji se odnose na učinke rashoda za obrazovanje i zdravstvo. Međutim, ovo ipak ne znači da su ove vrste rashoda irelevantne za rast u državama koje sačinjavaju uzorak. Naime, uzorak je sačinjen od ekonomija s višim srednjim dohotkom za koje je moguće da struktura i efikasnost rashoda ima veći učinak na rast od same razine rashoda. Aghion i Durlauf (2009), na primjer, ukazuju na povezanost strukture izdataka za obrazovanje i razine razvijenosti ističući pritom važnost visokog obrazovanja u državama koje se približavaju tehnološkoj granici. Drugim riječima, kod izdataka za obrazovanje i zdravstvo učinci koji osnažuju rast mogu biti sakriveni u njihovoj strukturi i efikasnosti. Razotkrivanje ovih učinaka zahtijeva daljnje istraživanje i za sada je ograničeno (ne)dostupnošću podataka.

Štoviše, ukoliko financiranje uključuje poreze (tj. kada se nedistorzivni porezi nalaze među ispuštenim varijablama) koeficijent uz ostale produktivne rashode je signifikantan, ali negativan (kolone 2 i 4). Proizlazi da povećanje produktivnih rashoda može imati negativne posljedice za rast ukoliko je financirano povećanjem poreza i to bez obzira na teoretski pretpostavljenu neutralnost nedistorzivnih poreza. Potrebno je naravno imati na umu da u funkcionalnoj klasifikaciji ova kategorija rashoda, zajedno s produktivnim rashodima za transport i komunikacije sadrži i neproduktivne vrste rashoda kao što su na primjer subvencije. Upravo ove statističke slabosti jesu razlog zbog kojeg se koristi i ekonomska klasifikacija.

Koeficijent uz fiskalni saldo je signifikantan i pozitivan ukoliko se implicitno financiranje ne temelji isključivo na oporezivanju (kolona 3 i 4). Ukoliko se, zbog smanjivanja neproduktivnih rashoda fiskalni saldo poboljša za I\%, stopa rasta realnog BDP-a će se povećati za o,52 postotna boda. S druge strane, poboljšanje fiskalnog salda financirano istodobnom promjenom nedistorzivnih poreza i neproduktivnih rashoda rezultirat će poboljšanjem stope rasta za o,36 postotnih bodova. Međutim, ukoliko se kao izvor smanjivanja deficita koristi samo povećanje nedistorzivnih poreza koeficijent uz fiskalni saldo je nesignifikantan. Pozitivne učinke snižavanja deficita na rast nalaze također i Kneller et al. (1999), Gupta et al. (2002) te Gemmell et al.(20II).

Kolone (5) do (7) prikazuju rezultate dobivene za rashodne varijable definirane temeljem ekonomske klasifikacije. Koeficijent uz državne investicije je pozitivan i signifikantan ukoliko su tekući rashodi ispušteni iz regresije što znači da porast investicijskih rashoda pridonosi ekonomskom rastu ukoliko je 
financiran smanjivanjem tekućih rashoda koji se pretežito sastoje od neproduktivnih rashoda. S druge strane, ukoliko je porast investicijskih rashoda financiran nedistorzivnim porezima tada povećanje državnih investicija ima zanemariv utjecaj na rast. Potrebno je, također, naglasiti da je koeficijent uz državne investicije, u apsolutnom iznosu, značajno manji od koeficijenta uz fiskalni saldo. Drugim riječima, čini se da je poboljšanje fiskalnog salda puno učinkovitiji način za osnaživanje rasta nego što je to povećanje državnih investicija.

Konačno, povećanje tekućih izdataka ima negativne učinke na rast, što je na određeni način komplementarno s rezultatima prikazanim u koloni (2). Povećanje tekućih izdataka za I\% koje je financirano povećanjem nedistorzivnih poreza smanjuje stopu rasta za o,32 postotna boda.

Prikazani rezultati upućuju na općeniti zaključak da fiskalna politika može imati pozitivne učinke na ekonomski rast kroz promjenu u strukturi ukupnih rashoda tj. pozitivni učinci na rast mogući su od snižavanja poreza i/ili povećanja državnih investicija ukoliko su te promjene financirane snižavanjem neproduktivnih i/ili tekućih rashoda. Dodatno, ovakve promjene mogu pridonijeti i snižavanju veličine državnog sektora koja onda ima vlastite pozitivne učinke na rast. Niža hirovitost državnih investicija je, također, povoljna za rast. Međutim, najsnažniji pozitivni učinci na ekonomski rast proizlaze iz poboljšanja fiskalnog salda i to naročito ako se poboljšanje fiskalnog salda ostvaruje smanjivanjem državnih rashoda. To znači da oprezna fiskalna politika može biti najbolji način za osnaživanje rasta.

\section{ANALIZA ROBUSTNOSTI}

\section{I. ENDOGENOST FISKALNIH VARIJABLI}

Uobičajeni problem $\mathrm{u}$ istraživanjima veze fiskalne politike $\mathrm{i}$ rasta je moguća obratna kauzalnost fiskalnih varijabli i rasta. Instrumentima fiskalne politike moguće je utjecati na rast outputa, ali je isto tako moguće da ekonomski rast određuje kretanje fiskalnih varijabli zbog čega se otvara mogućnost endogenosti fiskalnih varijabli. Određeni stupanj obratne kauzalnosti može se, također, pojaviti i između rasta i investicija. Moguća endogenost jedne ili više varijabli, koje se nalaze na desnoj strani regresije, uzrokuje pristranost i nekonzistentnost $\mathrm{u}$ ocjenama regresijskih koeficijenata. S obzirom da se u regresijama koje su ocijenjene temeljem modela iz izraza (I) pojavljuju varijable za koje je moguća pojava obratne kauzalnosti provedena je kontrola za učinak endogenosti. Iako endogenost ne mora biti značajan problem u regresijama koje uključuju dezagregirane fiskalne varijable, provjera njezinih mogućih učinaka na dobivene rezultate je provedena za sve ocijenjene jednadžbe.

Kontrola za mogući učinak endogenosti provedena je ocjenom dinamičkog modela na panel podacima i korištenjem ocjenjivača kojeg su predložili Arrellano i Bond (I99I). Arelleno-Bond ocjenjivač koristi poopćenu metodu momenata (GMM) kojom se parametri ocjenjuju na varijablama transformiranim u prve diferencije zbog čega se taj ocjenjivač naziva još i GMM ocjenjivač na prvim diferencijama (eng. first differenced GMM estimator).

Sve prethodno prikazane jednadžbe ocijenjene su još jedan put korištenjem Arellano-Bond ocjenjivača koji neopaženi učinak vezan uz pojedinu državu uklanja diferenciranjem, a razine endogenih varijabli s vremenskim pomakom se koriste kao instrumenti. Vremenski učinak se kontrolira uvođenjem slijepih varijabli. Snaga korištenih instrumenata je testirana korištenjem Sargan testa. ${ }^{\mathrm{I}}$ Ocjene parametara za regresijske jednadžbe koje uključuju fiskalne varijable su prikazane u tabeli 6.

\footnotetext{
${ }^{\mathrm{I}}$ Provedeno je također nekoliko testova za jedinični korijen. Levin, Lee i Chun test te Hadri test, koji pretpostavljaju zajednički proces jediničnog korijena za sve uključene cross-section jedinice, signaliziraju odbacivanje prisutnosti jediničnog korijena za sve testirane varijable s razinom signifikantnosti od $5 \%$. S druge strane, Im, Persan i Shin test te Fisher test, koji pretpostavljaju
} 
TABELA 6.

Učinci ukupnih fiskalnih varijabli na rast, kontrola za obratnu kauzalnost

Metoda ocjene: opća metoda momenata na prvim diferencijama

Zavisna varijabla: stopa rasta realnog BDP-a

\begin{tabular}{|c|c|c|c|c|}
\hline & \multirow{2}{*}{$\begin{array}{l}\text { Osnovna } \\
\text { regresija }\end{array}$} & \multicolumn{3}{|c|}{ Ispuštene fiskalne varijable } \\
\hline & & Fiskalni saldo & Ukupni prihodi & Ukupni rashodi \\
\hline $\mathbf{I}$ & 2 & 3 & 4 & 5 \\
\hline \multirow{2}{*}{ Stopa rasta $(-\mathrm{I})$} & 0,254 & $-0,226$ & $-0,257$ & $-0,196$ \\
\hline & $(\mathrm{O}, \mathrm{I} 89)$ & $(0, I 62)$ & $(\mathrm{O}, \mathrm{I} 64)$ & $(\mathrm{O}, \mathrm{I} 64)$ \\
\hline \multirow{2}{*}{ Investicije } & $0,094^{* *}$ & $\mathrm{O}, \mathrm{II} 7^{* * *}$ & $\mathrm{O}, \mathrm{I} 24^{* * *}$ & $0,122^{* * *}$ \\
\hline & $(\mathrm{O}, \mathrm{O} 37)$ & $(\mathrm{O}, \mathrm{O} 4 \mathrm{I})$ & $(\mathrm{O}, \mathrm{O} 4 \mathrm{I})$ & $(\mathrm{O}, \mathrm{O} 4 \mathrm{I})$ \\
\hline \multirow{2}{*}{ Stopa rasta radne snage } & $\mathrm{O}, 2 \mathrm{I} 3$ & $0,287^{* *}$ & $0,284^{* *}$ & $0,294^{* *}$ \\
\hline & $(\mathrm{O}, \mathrm{I} 4 \mathrm{O})$ & $(\mathrm{O}, \mathrm{I} 3 \mathrm{I})$ & $(\mathrm{O}, \mathrm{I} 25)$ & $(0,090)$ \\
\hline \multirow{2}{*}{ Otvorenost } & $\mathrm{O}, 2 \mathrm{I} 2^{* *}$ & $\mathrm{O}, \mathrm{I} 48^{* * *}$ & $\mathrm{O}, \mathrm{I} 48^{* * *}$ & $\mathrm{O}, \mathrm{I} 52^{* * *}$ \\
\hline & $(0,075)$ & $(0,025)$ & $(0,025)$ & $(0,025)$ \\
\hline \multirow{2}{*}{ Inflacija (-I) } & $-0,375$ & $-0,433^{*}$ & $-0,429^{*}$ & $-0,445^{*}$ \\
\hline & $(0,269)$ & $(0,225)$ & $(0,219)$ & $(0,23 \mathrm{I})$ \\
\hline \multirow{2}{*}{ Ukupni rashodi } & & $-0,33^{* * *}$ & $-\mathrm{O}, 4 \mathrm{OI}^{* * *}$ & \\
\hline & & $(0$, IO6) & $(\mathrm{O}, \mathrm{II} 6)$ & \\
\hline \multirow{2}{*}{ Ukupni prihodi } & & $-0,037$ & & $-0,348^{* * *}$ \\
\hline & & $(\mathrm{O}, \mathrm{I} 4 \mathrm{O})$ & & $(0,106)$ \\
\hline \multirow{2}{*}{ Fiskalni saldo $^{\text {I }}$} & & & $-0, I 55$ & $0,719^{* * *}$ \\
\hline & & & $(0,348)$ & $(0,244)$ \\
\hline \multirow{2}{*}{$\begin{array}{l}\text { Hirovitost državnih } \\
\text { investicija }(-\mathrm{I})\end{array}$} & $-0,0088^{* * *}$ & $-0,0033^{* *}$ & $-0,0032^{* *}$ & $-0,0034^{* *}$ \\
\hline & $(\mathrm{O}, \mathrm{OO} 2 \mathrm{I})$ & $(\mathrm{O}, \mathrm{OOI5})$ & (o,OOI5) & $(\mathrm{O}, \mathrm{OOI} 4)$ \\
\hline Broj opservacija & 143 & 129 & 129 & 129 \\
\hline Sargan test, $x^{2} p$-value & 0,33 & $\mathrm{O}, 2 \mathrm{I}$ & $0,3 \mathrm{I}$ & 0,22 \\
\hline Instrumenti & $\begin{array}{l}\text { Investicije, } \\
\text { pomak 2-3 }\end{array}$ & $\begin{array}{l}\text { Investicije, fiskalne } \\
\text { varijable, pomak 2-4 }\end{array}$ & $\begin{array}{c}\text { Investicije, fiskalne } \\
\text { varijable, pomak 2-4 }\end{array}$ & $\begin{array}{l}\text { Investicije, fiskalne } \\
\text { varijable, pomak 2-4 }\end{array}$ \\
\hline
\end{tabular}

Napomena: ${ }^{* *},{ }^{* *} i$ * označavaju signifikantnost na razini 1\%, 5\% i Io\%. Robustne standardne greške su prikazane u zagradama.

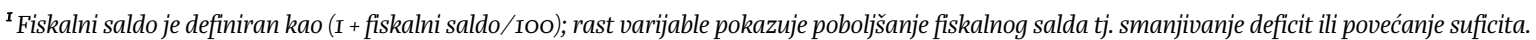

Dobiveni rezultati potvrđuju rezultate opisane u tabeli 4. Stopa rasta BDP-a s vremenskim pomakom je nesignifikantna, ali sve ostale nefiskalne varijable su zadržale očekivani predznak, iako uz nešto nižu razinu signifikantnosti. Signifikantnost koeficijenata uz fiskalne varijable je ostala nepromijenjena potvrđujući negativan učinak veličine državnog sektora na rast, kao i pozitivne učinke poboljšanja fiskalnog salda ukoliko se to poboljšanje financira smanjivanjem rashoda.

Tabela 7 prikazuje rezultate dinamičke analize za dezagregirane fiskalne varijable. Dobiveni rezultati u najznačajnijem potvrđuju rezultate modela s fiksnim učinkom za varijable rashoda i fiskalni saldo. Potvrđuje se da poboljšanje fiskalnog salda snižavanjem neproduktivnih rashoda ima pozitivan i signifikantan učinak na rast. Kao i u slučaju modela prikazanih u tabeli 5, pozitivni učinci povećanja produktivnih rashoda na rast nisu pronađeni. Porast produktivnih rashoda ponovo ima negativne učinke na rast ukoliko se njihova promjena financira porezima. Ukoliko se pak povećanje produktivnih rashoda implicitno financira snižavanjem neproduktivnih rashoda tada je njihov učinak na rast nesignifikantan.

$\mathrm{S}$ druge strane, $\mathrm{u}$ dinamičkom modelu nestaju pozitivni učinci državnih investicija na rast koji su pronađeni u modelima s fiksnim učinkom (kolona 6). Dodatno, dinamički model ne daje niti dokaze koji

individualan proces jediničnog korijena za svaku cross-section jedinicu signaliziraju moguću prisutnost jediničnog korijena u podacima za neproduktivne rashode te rashode za zdravstvo i državne investicije. Međutim, zbog kratke vremenske dimenzije panela ovi su testovi manje pouzdani. 
bi potvrdili da snižavanje poreza, uključujući i distorzivne poreze, koje se financira snižavanjem neproduktivnih rashoda ima pozitivne učinke na rast. Kao što je prikazano u kolonama (2) do (4) pozitivni učinci snižavanja poreza na rast nisu pronađeni. Negativni učinci hirovitosti državnih investicija potvrđeni su i dinamičkim modelima.

\section{TABELA 7.}

Učinci dezagregiranih fiskalnih varijabli na rast, kontrola za obratnu kauzalnost

Metoda ocjene: opća metoda momenata na prvim diferencijama

Zavisna varijabla: realna stopa rasta BDP-a

\begin{tabular}{|c|c|c|c|c|c|c|}
\hline \multirow[b]{2}{*}{$\begin{array}{l}\text { Ispuštene } \\
\text { fiskalne varijable }\end{array}$} & \multicolumn{3}{|c|}{ Funkcionalna klasifikacija rashoda } & \multicolumn{3}{|c|}{ Ekonomska klasifikacija rashoda } \\
\hline & $\begin{array}{c}\text { Nedistorzivni } \\
\text { porezi }\end{array}$ & $\begin{array}{l}\text { Neproduktivni } \\
\text { rashodi }\end{array}$ & $\begin{array}{c}\text { Nedistorzivni } \\
\text { porezi i } \\
\text { neproduktivni } \\
\text { rashodi }\end{array}$ & $\begin{array}{c}\text { Nedistorzivni } \\
\text { porezi }\end{array}$ & $\begin{array}{l}\text { Tekući } \\
\text { rashodi }\end{array}$ & $\begin{array}{l}\text { Nedistorzivni } \\
\text { porezi i tekući } \\
\text { rashodi. }\end{array}$ \\
\hline $\mathbf{I}$ & 2 & 3 & 4 & 5 & 6 & 7 \\
\hline \multirow{2}{*}{ Stopa rasta $(-\mathrm{I})$} & $-0,189$ & $-0, I 3 I$ & $-0,094$ & $-0, I 76$ & $-0,058$ & 0,007 \\
\hline & $(0,175)$ & $(\mathrm{O}, \mathrm{I} 4 \mathrm{I})$ & $(0,166)$ & $(\mathrm{O}, \mathrm{I60})$ & $(0,139)$ & $(\mathrm{O}, \mathrm{I} 4 \mathrm{O})$ \\
\hline \multirow{2}{*}{ Investicije } & $0,135^{* *}$ & $0,133^{* *}$ & $0,127^{* *}$ & $0,085^{*}$ & $0,107^{* *}$ & $0,098^{* *}$ \\
\hline & $(\mathrm{O}, 06 \mathrm{I})$ & $(0,057)$ & $(0,064)$ & $(0,043)$ & $(0,042)$ & $(0,039)$ \\
\hline \multirow{2}{*}{ Stopa rasta radne snage } & $0,278^{* * *}$ & $0,3 \mathrm{I} 4^{* *}$ & $0,240^{* *}$ & $0,366^{* * *}$ & $0,258^{* *}$ & $\mathrm{O}, 2 \mathrm{II}$ \\
\hline & $(0, I I 7)$ & $(0,08 \mathrm{I})$ & $(\mathrm{O}, \mathrm{IO} 4)$ & $(\mathrm{O}, \mathrm{IO} 7)$ & $(0$, IO5) & $(0,137)$ \\
\hline \multirow{2}{*}{ Otvorenost } & $0,143^{* * *}$ & $0,096^{* * *}$ & $\mathrm{O}, \mathrm{I} 35^{* * *}$ & $\mathrm{O}, \mathrm{I} 4 \mathrm{O}^{* * *}$ & $0,158^{* * *}$ & $\mathrm{O}, \mathrm{I} 7 \mathrm{I}^{* * *}$ \\
\hline & $(0,036)$ & $(0,038)$ & $(\mathrm{O}, \mathrm{O} 4 \mathrm{I})$ & $(0,033)$ & $(0,025)$ & $(0,032)$ \\
\hline \multirow{2}{*}{ Inflacija (-I) } & $-0,399^{* * *}$ & $-0,289^{* * *}$ & $-0,305^{* *}$ & $-0,448^{* *}$ & $-0,288^{*}$ & $-0,306$ \\
\hline & $(0,134)$ & $(\mathrm{O}, \mathrm{IO} 5)$ & $(\mathrm{O}, \mathrm{I} 45)$ & $(0,222)$ & $(0,167)$ & $(\mathrm{O}, 2 \mathrm{II})$ \\
\hline \multirow{2}{*}{ Distorzivni porezi } & O,I99 & $-0,006$ & 0,064 & $\mathrm{O}, \mathrm{I} 2 \mathrm{I}$ & $-0,037$ & $-\mathrm{O}, \mathrm{I} 3 \mathrm{I}$ \\
\hline & $(0,126)$ & $(0,077)$ & $(\mathrm{O}, \mathrm{IO} 7)$ & $(0,152)$ & $(\mathrm{O}, \mathrm{IO} 2)$ & $(0,050)$ \\
\hline \multirow{2}{*}{ Nedistorzivni porezi } & - & -O,IO9 & - & - & $-0,070$ & - \\
\hline & & $(0,070)$ & & & $(0,056)$ & \\
\hline \multirow{2}{*}{ Ostali prihodi } & 0,025 & $-0,024$ & $-0,055$ & 0,049 & $-0,030$ & $-0,039$ \\
\hline & $(0,024)$ & $(0,017)$ & $(0,027)$ & $(0,046)$ & $(0,025)$ & $(0,018)$ \\
\hline \multirow{2}{*}{ Produktivni r._zdravstvo } & $-0,082^{* * *}$ & $-0,006$ & $-0,009$ & & & \\
\hline & $(0,029)$ & $(0,044)$ & $(0,043)$ & & & \\
\hline \multirow{2}{*}{ Produktivni r._obrazovanje } & $-0,077$ & $\mathrm{O}, \mathrm{O} 3 \mathrm{O}$ & 0,008 & & & \\
\hline & $(0,060)$ & $(0,076)$ & $(0,076)$ & & & \\
\hline \multirow{2}{*}{ Ostali produktivni rashodi } & $-0,196^{* * *}$ & $-0,064$ & $-0,074^{*}$ & & & \\
\hline & $(0,073)$ & $(0,047)$ & $(\mathrm{O}, \mathrm{O} 4 \mathrm{I})$ & & & \\
\hline \multirow{2}{*}{ Neproduktivni rashodi } & $-0,193^{* *}$ & - & - & & & \\
\hline & $(0,084)$ & & & & & \\
\hline \multirow{2}{*}{ Fiskalni saldo $^{\mathrm{I}}$} & $-0,535$ & $0,697^{*}$ & $0,44 I^{*}$ & $-0,606$ & $0,679^{* *}$ & $0,636^{* *}$ \\
\hline & $(0,388)$ & $(0,375)$ & $(0,246)$ & $(0,494)$ & $(0,284)$ & $(0,274)$ \\
\hline \multirow{2}{*}{ Tekući rashodi } & & & & $-0,546^{* * *}$ & - & - \\
\hline & & & & $(0,192)$ & & \\
\hline \multirow{2}{*}{ Državne investicije } & & & & $-0,056$ & $-0, I 43$ & $-0,005$ \\
\hline & & & & $(0,037)$ & $(0,019)$ & $(0,016)$ \\
\hline \multirow{2}{*}{$\begin{array}{l}\text { Hirovitost državnih } \\
\text { investicija (-I) }\end{array}$} & $-0,0029^{* *}$ & $-0,0034^{* * *}$ & $-0,0030^{* * *}$ & $-0,0030^{* *}$ & $-0,0029^{* * *}$ & $-0,0033^{* * *}$ \\
\hline & $(0,0012)$ & (o,ooog) & (o,OOIO) & $(0,0013)$ & $(0,0008)$ & $(0,0007)$ \\
\hline Broj opservacija & 129 & II2 & II2 & I29 & 129 & I29 \\
\hline Sarganov test, $\chi^{2} \mathrm{p}$-value & 0,30 & 0,14 & 0,48 & 0,27 & 0,13 & $0, I 6$ \\
\hline Instrumenti & $\begin{array}{l}\text { Investicije, } \\
\text { fiskalne var., } \\
\text { pomak 2-4 }\end{array}$ & $\begin{array}{l}\text { Investicije, } \\
\text { fiskalne var., } \\
\text { pomak 2-5 }\end{array}$ & $\begin{array}{l}\text { Investicije, } \\
\text { fiskalne var., } \\
\text { pomak 2-5 }\end{array}$ & $\begin{array}{l}\text { Investicije, } \\
\text { fiskalne var., } \\
\text { pomak 2-4 }\end{array}$ & $\begin{array}{l}\text { Investicije, } \\
\text { fiskalne var., } \\
\text { pomak 2-4 }\end{array}$ & $\begin{array}{l}\text { Investicije, } \\
\text { fiskalne var., } \\
\text { pomak } 2-4\end{array}$ \\
\hline
\end{tabular}

Napomena: ***, ** $i$ * označavaju signifikantnost na razini I\%, 5\% i Iо\%. Robustne standardne greške su prikazaneu zagradama.

${ }^{\mathrm{I}}$ Fiskalni saldo je definiran kao (I + fiskalni saldo/Ioo); rast varijable pokazuje poboljšanje fiskalnog salda tj. smanjivanje deficit ili povećanje suficita. 


\subsection{ALTERNATIVNA KLASIFIKAGIJA PRODUKTIVNIH RASHODA}

Kao što je već prethodno istaknuto, klasificiranje pojedinačnih funkcionalnih kategorija rashoda u produktivne i neproduktivne nije jednoznačno, pa postoji mogućnost da odluka o načinu njihova razvrstavanja utječe na rezultate provedene regresijske analize. Jedan od mogućih primjera su rashodi za opće javne usluge koje najveći broj istraživača razvrstava u neproduktivne dok polit ekonomisti ukazuju na njihovu važnost u izgradnji institucija. Tabela 8 prikazuje rezultate dobivene za alternativnu definiciju produktivnih rashoda u kojoj su izdaci za opće javne usluge razvrstani u "ostale produktivne izdatke”. U kolonama (2) do (4) su prikazani rezultati modela s dvostranim fiksnim učinkom dok se u kolonama (5) do (8) prikazuju rezultati dinamičke analize.

Koeficijenti uz makroekonomske nefiskalne varijable nisu prikazani jer su njihov predznak i razina signifikantnosti ostali nepromijenjeni.

Reklasifikacija izdataka za opće javne usluge iz neproduktivnih u produktivne rashode nije donijela značajnije promjene rezultata. Kada financiranje uključuje mogućnost povećanja poreza, koeficijent $\mathrm{i}$ uz ovako proširene 'ostale produktivne rashode' je negativan i to bez obzira na obilježja korištene metode ocjene (kolone 2 i 4, te 5 i 7). Neproduktivni rashodi, uz sada uži obuhvat, zadržavaju svoj statistički signifikantan i negativan predznak u analizi s dvostranim fiksnim učinkom.

\section{TABELA 8.}

Reklasifikacija rashoda za opće javne usluge

Zavisna varijabla: stopa rasta realnog BDP-a

\begin{tabular}{|c|c|c|c|c|c|c|}
\hline \multirow{3}{*}{ Metoda ocjene } & \multirow{2}{*}{\multicolumn{3}{|c|}{$\begin{array}{l}\text { OLS, dvostrani fiksni učinak } \\
\text { Ispuštena fiskalna varijabla }\end{array}$}} & \multirow{2}{*}{\multicolumn{3}{|c|}{$\begin{array}{c}\text { GMM, prve diferencije } \\
\text { Ispuštena fiskalna varijabla }\end{array}$}} \\
\hline & & & & & & \\
\hline & $\begin{array}{l}\text { Nedistorz. } \\
\text { porezi }\end{array}$ & $\begin{array}{l}\text { Neprod. } \\
\text { rashodi }\end{array}$ & $\begin{array}{l}\text { Nedistor. } \\
\text { por./neprod. } \\
\text { rashodi }\end{array}$ & $\begin{array}{l}\text { Nedistorz. } \\
\text { porezi }\end{array}$ & $\begin{array}{l}\text { Neprod. } \\
\text { rashodi }\end{array}$ & $\begin{array}{l}\text { Nedistor. } \\
\text { por./neprod. } \\
\text { rashodi }\end{array}$ \\
\hline $\mathbf{I}$ & 2 & 3 & 4 & 5 & 6 & 7 \\
\hline \multirow{2}{*}{ Distorzivni porezi } & 0,048 & $-0,079^{* *}$ & $-0,040$ & $\mathrm{O}, 2 \mathrm{II}$ & o,oog & $\mathrm{O}, \mathrm{O} 72$ \\
\hline & $(0,053)$ & $(0,04 \mathrm{I})$ & $(0,056)$ & $(\mathrm{O}, \mathrm{I} 5 \mathrm{O})$ & $(0,083)$ & $(\mathrm{O}, \mathrm{I} 2 \mathrm{I})$ \\
\hline \multirow{2}{*}{ Nedistorzivni porezi } & - & $-0,093^{* *}$ & - & - & $-0,095$ & - \\
\hline & & $(0,044)$ & & & $(0,067)$ & \\
\hline \multirow{2}{*}{ Ostali prihodi } & 0,024 & $-0,004$ & 0,002 & 0,023 & $-0,003$ & 0,040 \\
\hline & $(\mathrm{O}, \mathrm{OI} 2)$ & $(\mathrm{O}, \mathrm{OII})$ & $(\mathrm{O}, \mathrm{OI} 2)$ & $(0,035)$ & $(0,020)$ & $(\mathrm{O}, \mathrm{O} 3 \mathrm{I})$ \\
\hline \multirow{2}{*}{ Produk. rash._zdravstvo } & $-0,028$ & 0,004 & $-0,013$ & $-0,12 I^{*}$ & $-0,028$ & $-0,02 I$ \\
\hline & $(\mathrm{O}, \mathrm{OI} 8)$ & (o,ol9) & (o,ol9) & $(0,04 \mathrm{I})$ & $(0,029)$ & $(0,039)$ \\
\hline \multirow{2}{*}{ Produk.rash._obrazovanje } & 0,007 & 0,027 & 0,070 & $-0,038$ & o,o39 & $\mathrm{O}, \mathrm{OI} 5$ \\
\hline & $(0,035)$ & $(0,04 \mathrm{I})$ & $(\mathrm{O}, \mathrm{O} 4 \mathrm{I})$ & $(0,069)$ & $(0,074)$ & $(0,064)$ \\
\hline \multirow{2}{*}{ Ostali produktivni rashodi } & $-0,132^{* * *}$ & $-0,035$ & $-0,07 I^{* *}$ & $-0,256^{* *}$ & $-0,050$ & $-0, \mathrm{I}_{3}^{*}$ \\
\hline & $(0,027)$ & $(0,030)$ & $(0,023)$ & $(0,098)$ & $(0,065)$ & $(0,067)$ \\
\hline \multirow{2}{*}{ Neproduktivni rashodi } & $-\mathrm{O}, \mathrm{I} 3 \mathrm{I}^{* * *}$ & - & - & $-0,109$ & - & - \\
\hline & $(0,040)$ & & & $(0,084)$ & & \\
\hline \multirow{2}{*}{ Fiskalni saldo $^{\mathrm{I}}$} & $-0,202$ & $0,448^{* *}$ & $0,370^{* *}$ & $-0,0367$ & $0,786^{*}$ & $0,484^{*}$ \\
\hline & $(0,24 I)$ & $(0,194)$ & $(0,188)$ & $(0,372)$ & $(0,407)$ & $(0,284)$ \\
\hline \multirow{2}{*}{ Hirovitost državnih inv. (-I) } & $-0,0024^{* * *}$ & $-0,0027^{* * *}$ & $-0,0029^{* * *}$ & $-0,0029^{* * *}$ & $-0,0032^{* * *}$ & $-0,0032^{* * *}$ \\
\hline & $(0,0006)$ & $(0,0006)$ & $(0,0006)$ & $(0,00 I 4)$ & $(0,0009)$ & $(0,0013)$ \\
\hline $\mathrm{R}^{2 \sim}$ & 0,835 & $0,8 \mathrm{I} 9$ & $\mathrm{o}, 8 \mathrm{O} 3$ & & & \\
\hline Broj opservacija & 156 & I56 & 156 & 129 & II2 & II2 \\
\hline Sarganov test, $x^{2} p$-vrijednosti & & & & $0,5 \mathrm{I}$ & O,I9 & 0,39 \\
\hline Instrumenti & & & & $\begin{array}{l}\text { Investicije, } \\
\text { fiskalne var., } \\
\text { pomak 2-4 }\end{array}$ & $\begin{array}{l}\text { Investicije, } \\
\text { fiskalne var., } \\
\text { pomak 2-5 }\end{array}$ & $\begin{array}{l}\text { Investicije, } \\
\text { fiskalne var., } \\
\text { pomak 2-5 }\end{array}$ \\
\hline
\end{tabular}

Napomena: ${ }^{* *},{ }^{* *} i *$ označavaju signifikantnost na razini 1\%, $5 \%$ i Io\%. Robustne standardne greške su prikazane u zagradama.

${ }^{I}$ Fiskalni saldo je definiran kao (I + fiskalni saldo/Ioo); rast varijable pokazuje poboljšanje fiskalnog salda tj. smanjivanje deficita ili povećanje suficita. 


\section{ZAKLJUČAK}

Rezultati empirijskog istraživanja prikazani u ovom članku nisu osigurali dokaze o snažnoj povezanosti instrumenata fiskalne politike i gospodarskog rasta u novim članicama EU. Teorijska predviđanja o pozitivnim učincima rashoda za zdravstvo i obrazovanje na ovom uzorku država nisu potvrđena. S druge strane, pozitivna veza državnih investicija i rasta nije potvrđena u dinamičkoj analizi. Štoviše, pozitivan utjecaj državnih investicija na rast se pojavljuje jedino u uvjetima promjena u strukturi ukupnih rashoda tj. kada se povećanje državnih investicija financira snižavanjem neproduktivnih rashoda. To signalizira da je pojava pozitivnih učinaka državnih investicija na rast moguća ako se pri tome otvara mogućnost smanjivanja ukupne veličine državnog sektora za koju smo pokazali da ima povoljne učinke na rast. Ovakvi rezultati jesu donekle iznenađujući i zahtijevaju daljnje istraživanje posebno u dijelu koji se odnosi na detaljnije dezagregiranje podataka o rashodima za zdravstvo, obrazovanje i investicije.

S druge strane pronađeni su čvrsti dokazi da hirovitost državnih investicija ima vlastite negativne učinke na rast nezavisne od učinaka koje na rast ostvaruje razina državnih investicija. Iznenadne $\mathrm{i}$ snažne promjene u visini državnih investicija nisu povoljne za rast.

Nisu pronađeni dokazi koji bi potvrdili da promjene u strukturi oporezivanja $\mathrm{u}$ korist indirektnih poreza tj. poreza na dobra i usluge imaju pozitivne učinke na rast. Financiranje javnih investicija ili snižavanje fiskalnog salda povećanjem nedistorzivnih poreza ima manje-više jednako negativne učinke na rast kao i povećanje distorzivnih poreza.

S druge strane, poboljšanje fiskalnog salda ostvareno bilo snižavanjem neproduktivnih rashoda ili kombinacijom snižavanja neproduktivnih rashoda i povećanja nedistorzivnih poreza ima snažne pozitivne učinke na rast. Pokazuje se stoga da je, za promatranu skupinu država, poboljšanje fiskalnog salda odnosno snižavanje deficita najdjelotvorniji način na koji fiskalna politika može osnažiti i potaknuti rast. 


\section{PRILOG}

\section{IZVORI PODATAKA I OPIS VARIJABLI}

Države uključene u uzorak su: Slovenija, Mađarska, Poljska, Slovačka, Češka, Bugarska, Rumunjska, Estonija, Litva, Latvija, Malta i Cipar tj. nove članice EU plus Hrvatska. Izvori podataka uključuju bazu podataka Eurostata, WDI bazu podataka koju izrađuje Svjetska banka i nacionalne izvore za Hrvatsku.

Ukoliko nije drugačije navedeno, izvor podataka za nefiskalne varijable je baza Eurostata dostupna na: http://epp.eurostat.ec.europa.eu/portal/page/portal/statistics /search_database.

Stopa rasta realnog outputa je izračunata kao razlika logaritama realnog BDP-a per capita u konstantnim jedinicama nacionalne valute $s$ baznom 2005. godinom. Podaci za Maltu i Cipar za 1999.200o. nisu dostupni u Eurostatovoj bazi podataka zbog čega se koristi WDI baza.

Koristi se realni BDP per capita u konstantnim eurima.

Investicije se mjere udjelom investicija za formiranje bruto fiksnog kapitala u BDP-u.

Stopa rasta radne snage je razlika logaritama stope aktivnosti pri čemu je stopa aktivnosti definirana kao udio aktivne populacije ( $15-65$ godina starosti) u ukupnoj populaciji te dobne skupine.

Otvorenost je definirana kao udjel izvoza i uvoza roba i usluga u BDP-u. Izvor podataka je WDI baza podataka dostupna na http://databank.worldbank.org/data/home.aspx.

Inflacija je definirana izrazom I + godišnja stopa promjene potrošačkih cijena/Ioo. Izvor podataka je WDI baza.

Izvor podataka za sve fiskalne varijable, osim za Hrvatsku, je Eurostatova baza dostupna na http://epp.eurostat.ec.europa.eu/portal/page/portal/statistics/search_database. Za Hrvatsku se koriste nacionalni izvori i izračuni autorice. Sve fiskalne varijable se odnose na opću državu i odgovaraju ESA statističkom standardu (osim djelomično za Hrvatsku). Sve varijable su definirane kao logaritmi udjela u BDP-u.

Ukupni prihodi su udio ukupnih prihoda opće države u BDP-u.

Ukupni rashodi su udio ukupnih rashoda opće države u BDP-u.

Fiskalni saldo je definiran kao (I+fiskalni saldo/IOo) pri čemu povećanje ove varijable znači smanjivanje deficita/povećanje suficita i obratno.

Distorzivni porezi, nedistorzivni porezi i ostali prihodi izraženi su njihovim postotnim udjelom u BDPu i označavaju dezagregirane komponente ukupnih prihoda kako je opisano u tabeli I.

Produktivni rashodi_zdravstvo, produktivni rashodi_obrazovanje i ostali produktivni rashodi su varijable dobivene agregiranjem pojedinih funkcionalnih komponenti ukupnih rashoda (opisano $\mathrm{u}$ tabeli I). Sve ove varijable izražene su njihovim udjelom u BDP-u.

Tekući i investicijski rashodi jesu varijable dobivene agregiranjem pojedinih ekonomskih komponenti ukupnih rashoda (opisano u tabeli I). Obje varijable su izražene udjelom u BDP-u. 


\section{METODOLOŠKO UPOZORENJE ZA HRVATSKU}

Počevši od 2002. za Hrvatsku su dostupni fiskalni podaci temeljeni na standardu GFS2OoI. Uz to su u različitim dokumentima EU od 2003. nadalje dostupne i procjene hrvatskih fiskalnih agregata (ukupni prihodi, ukupni rashodi i fiskalni saldo) sukladne metodologiji ESA95. S obzirom da sličnosti između GFS2OoI i ESA95 standarada dopuštaju kvalitetnu usporedbu pojedinačnih komponenti prihoda i rashoda, dezagregirane fiskalne varijable su definirane temeljem podataka zasnovanih na GFS2OoI standardu dok su agregatne fiskalne varijable zasnovane na ESA95 standardu.

S obzirom da su službeni podaci prema GFS2OoI standardu dostupni nakon 2002, opažanja za 1999.200I. su izračun autorice koji se temelji na prilagodbi podataka zasnovanih na GFSig86. Prilagodbe su u najvećoj mjeri povezane s tretmanom stavki "doprinosi poslodavaca" i "neto posudbe i otplate". Međutim, za očekivati je da, i nakon odgovarajuće prilagodbe GFSig86 podataka, vrijednost ukupnih rashoda u razdoblju 1999.-2003. i dalje ostaje podcijenjena, u odnosu na pravu ESA95 vrijednost, zbog nedostajućih podataka o protestiranim državnim jamstvima.

Funkcionalna klasifikacija rashoda opće države u Hrvatskoj također nije dostupna. Izračuni autorice se temelje na podacima za središnju državu i transakcijama između različitih razina državne vlasti. Međutim, izdaci središnje države čine 93 posto ukupnih izdataka opće države zbog čega smatramo da su učinjene prilagodbe vjerodostojne. 


\section{REFERENGE}

I. Acemoglu, D. i Robinson J. A., 2012. Why Nations Fail. New York: Crown Business.

2. Adam, C. S. i Bevan, D. L., 2005. Fiscal deficits and growth in developing countries. Journal of Public Economics, 89(4), str. 57I-597. doi: I0.IOI6/j.jpubeco.2004.02.006

3. Afonso, A. i Furceri, D., 2008. Government Size, Composition and Economic Growth. ECB Working Paper, No. 849 [online]. Dostupno na: [http://www.ecb.europa.eu/pub/pdf/scpwps/ecbwp849.pdf].

4. Aghion, P. [et al.], 2005. Volatility and Growth: Credit Constraints and Productivity-Enhancing Investment. NBER Working Paper II349 [online]. Dostupno na: [http://www.nber.org/papers/WII349.pdf?new_window=I].

5. Aghion, P. i Durlauf, S., 2009. From Growth theory to Policy Design. The Commission on Growth and Development [online]. Dostupno na: [www.growthcommission.org].

6. Aghion, P. i Howitt, P., I990. A Model of Growth through Creative Destruction. NBER Working paper 3223 [online]. Dostupno na: [http://www.nber.org/papers/w3223.pdf].

7. Aghion, P., 2009. Growth and Education. The Commission on Growth and Development [online]. Dostupno na: [www.growthcommission.org].

8. Akitoby, B. [et al.], 2004. The Cyclical i Long Term Behaviour of Government Expenditures in Developing Countries. IMF Working Paper 04/2O2 [online]. Dostupno na: [http://www.imf.org/external/pubs/ft/wp/2004/wpo4202.pdf].

9. Alesina, A. [at al.], 2002. Fiscal Policy, Profits and Investment. American Economic Review, 92(3), str. 57I-589. doi: I0.1257/00028280260136255

IO. Alesina, A. i Ardagna, S., 2009. Large Changes in Fiscal Policy: Taxes vs. Spending. NBER Working Paper I5438 [online]. Dostupno na: [http://www.nber.org/papers/WI5438.pdf?new_window=I].

II. Arellano, M. i Bond, S., 199I. Some Tests of Specification for Panel data: Monte Carlo Evidence and an Application to Employment Equations. Review of Economic Studies, 58(2), str. 277-297. doi: I0.2307/2297968

12. Aschauer, D. A., I988. Is Public Expenditure Productive? Journal of Monetary Economics, 23, str. I77200. doi: IO.IOI6/0304-3932(89)90047-O

I3. Barlevy, G., 2003. The Costs of Business Cycles under Endogenous Growth. NBER Working Paper 9970 [online]. Dostupno na: [http://www.nber.org/papers/w9970.pdf?new_window=I].

I4. Barro, R. J., 1990. Government Spending in a Simple Model of Endogenous Growth. Journal of Political Economy, 98 (5), str. I03-II7. doi: IO.IO86/26I726

I5. Barro, R. J., 2003. Determinants of Economic Growth in a Panel of Countries. Annals of Economics and Finance, 4(2), str. 23I-27I.

I6. Barro, R., I974. Are Government Bonds Net Wealth. Journal of Political Economy, 82(6), str. I095-III7. doi: $10.1086 / 260266$

17. Blanchard, O. J., 199o. A Comment in O. Blanchard i S. Fisher, eds. NBER Macroeconomic Annual I990. Cambridge: MIT Press, str. III-II5.

I8. Bleaney, M., Gemmell, N. i Kneller, R., 200I. Testing the Endogenous Growth Model; Public Expenditure, Taxation and Growth Over the Long Run. Canadian Journal of Economics, 34(I), str. 3657. doi: IO.IIII/O008-4085.0006I

19. Bloom, D. E., Canning, D. i Sevilla, J., 200I. The Effect of Health on Economic Growth: Theory and Evidence. NBER Working Paper 8587 [online]. Dostupno na: [http://www.nber.org/papers/w8587.pdf?new_window=I].

20. Bond, S., 2002. Dynamic Panel Data Models: A Guide to Micro Data Methods i Practice. Portuguese Economic Journal, I(2), str. I4I-I62. doi: IO.I920/wp.cem.2002.0902

2I. Canning, D. i Pedroni, P., 2004. The Effect of Infrastructure on Long Run Economic Growth. Department of Economic Working Paper, 2004-04 [online]. Dostupno na: [http://web.williams.edu/Economics/wp/pedronniinfrastructure.pdf].

22. Dalić, M., 2013. Cyclical Properties of Fiscal Policy in NMS. Journal of Post-Communist Economies, 25(3), str. 289-308. doi: 10.1080/I4631377.2013.8I3I44.

23. de Avila, D. R. i Strauch, R., 2003. Public Finance and Long Term Growth in Europe - Evidence From Panel Data Analysis. ECB Working Paper 246 [online]. Dostupno na: [http://www.ecb.europa.eu/pub/pdf/scpwps/ecbwp246.pdf].

24. Devarajan, S., Swaroop, V. i Zou, H., I996. The Composition of Public Expenditure and Economic Growth. Journal of Monetary Economics, 37(2-3), str. 3I3-344. doi: IO.IOI6/03O4-3932(96)OI249-4

25. Easterly, W. i Rebelo, S., I993. Fiscal Policy and Economic Growth: An Empirical Investigation. Journal of Monetary Economics, 32(3), str. 4I7-458. doi: Io.IOI6/O304-3932(93)90025-B 
26. Fatas, A. i Mihov, I., 2003. The Case for Restricting Fiscal Policy Discretion. The Quarterly Journal of Economics, II8(4), str. I4I9-I448. doi: Io.II62/o033553O3322552838

27. Fatas, A. i Mihov, I., 2009. Macroeconomic Policy: Does it Matter for Growth The Role of Volatility. Commission on Growth and Development, Working paper, No. 48 [online]. Dostupno na: [http://www.gcbpp.org/files/Academic_Papers/fatas/AP_MacroeconomicPolicy_WorldBank_II2 oog.pdf].

28. Gemmell, N., 200I. Fiscal Policy in a Growth Framework. WIDER Discussion paper. 84 [online]. Dostupno na: [https://www.econstor.eu/dspace/bitstream/I0419/53009/I/335I32III.pdf].

29. Gemmell, N., Kneller, R. i Sanz, I., 2OII. Fiscal Policy Impact on Growth in the OECD: Are They LongRun?. The Economic Journal, I2I(55), str. F33-F58. doi: IO.IIII/j.I468-0297.20I0.024I4.x

30. Gupta, S. [et al.], 2002. Expenditure Composition, Fiscal Adjustments and Growth in Low Income Countries. Working paper 77 [online]. Dostupno na: [http://www.imf.org/external/pubs/ft/wp/2002/wpo277.pdf].

3I. Hnatkovska, V. i Loayza, N., 2004. Volatility and Growth. World Bank Policy Research Paper, 3I84. Washington D. C.: The World Bank.

32. Irmen, A. i Kuehnel, J., 2009. Productive Government Expenditures and Economic Growth. Journal of Economic Surveys, 23(4), str. 692-733. doi: I0.IIII/j.I467-6419.2009.00576.x

33. King, R. G. i Rebelo, S., 1990. Public Policy and Economic Growth: Developing Neoclassical Implications. Journal of Political Economy, 98(3), str. 126-150. doi: 10.1086/261727

34. Kneller, R., Bleaney, M. i Gemmell, N., 1999. Fiscal Policy and Growth: Evidence from OECD Countries. Journal of Public Economics, 74(2), str. I7I-I9O. doi: IO.IOI6/SoO47-2727(99)0oo22-5

35. La Porta, R. [et al.], 1996. Law and Finance. NBER Working Paper 566I [online]. Dostupno na: [http://www.nber.org/papers/W5661.pdf?new_window=I].

36. Levine, R. i Renelt, D., 1998. A Sensitivity Analysis of Cross Country Growth Regressions. American Economic Journal, 82(4), str. 942-963.

37. Lucas, R., I988. On the Mechanics of Economic Development. Journal of Monetary Economics, 22(I), str. 3-42. doi: IO.IOI6/0304-3932(88)90168-7

38. Romer, P. M., 1990. Endogenous Technological Change. Journal of Political Economy, 98(5), pp, S7ISIO2.

39. Zagler, M. i Dürnecker, G., 2003. Fiscal Policy and Economic Growth. Journal of Economic Surveys, I7(3), str. 397-4I8. doi: IO.IIII/I467-64I9.00I99 